


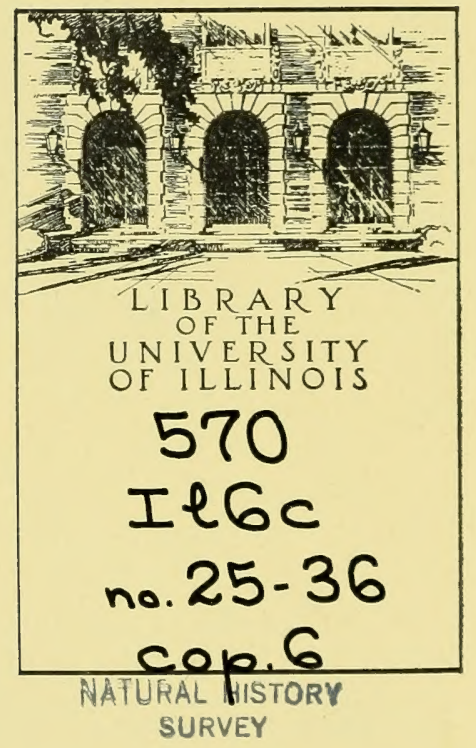

NATURAL. 
Digitized by the Internet Archive in 2010 with funding from University of Illinois Urbana-Champaign 

570
$186 \mathrm{c}$
0.26 Cops

INSEGTE ENI MUTSS

- of the

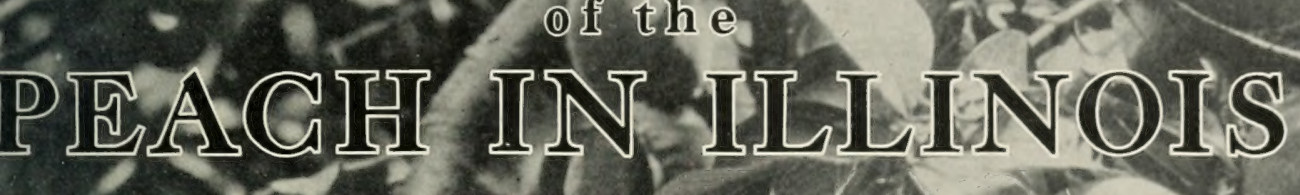

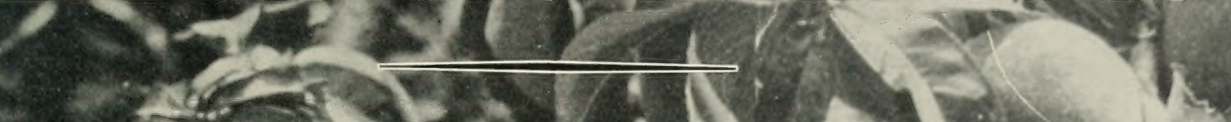

S. G. CHANDIER AND W P. FLINT)

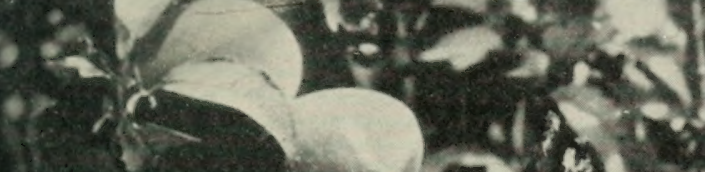

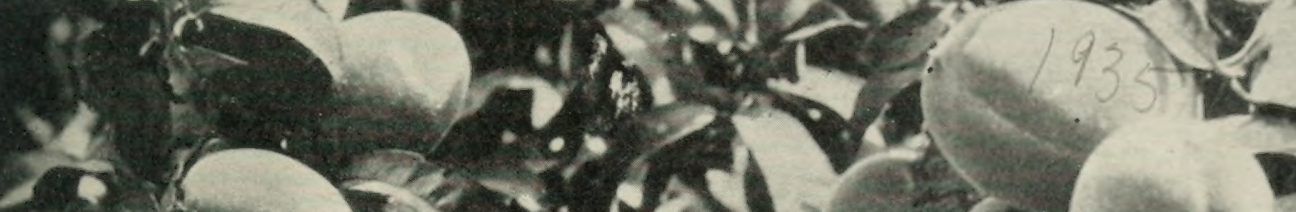

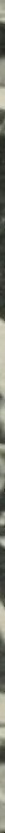

IILINOIS NATURAL FISTORY SURVEY GIRGUIAR 26

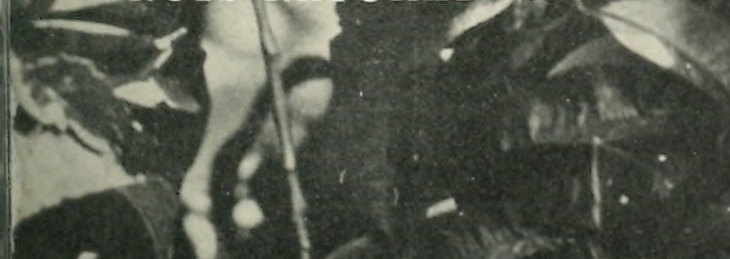





\section{Insect Enemies of the Peach in Illinois}

S. C. CHANDLER AND W. P. FLINT

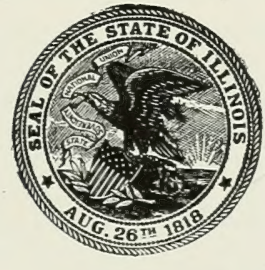

Printed by authority of the State of Illinois

Department of Registration and Education NATURAL HISTORY SURVEY DIVISION

Theodore H. Frison, Chief

Circular 26

Urbana

May 1935 


\section{STATE OF ILLINOIS \\ Honorable Henry Horner, Governor DEPARTMENT OF REGISTRATION AND EDUCATION Honorable John J. Hallihan, Director}

\section{BOARD OF NATURAL RESOURCES AND CONSERVATION \\ Honorable John J. Hallahan, Chairman}

William Trelease, D.Sc., LL.D., Biology

Henry C. Cowles, Ph.D., D.Sc., Forestry

John W. Alvord, C.E., Engineering
William A. Noyes, Ph.D., LL.D., Chem.D., D.Sc., Chemistry

Edson C. Bastin, Ph.D., Geology

Arthur Cutts Willard, D.Eng., LI.D.,

President of the University of Illinois

\section{NATURAL HISTORY SURVEY DIVISION}

URBANA, ILLINOIS

Scientific and Technical Staff

Theodore H. Frison, Ph.D., Chief

\section{SECTION OF ECONOMIC ENTOMOLOGY}

W. P. Flint, B.S., Chief Entomologist

C. C. Сompton, M.S., Associate Entomologist

M. D. Farrar, Ph.D., Research Entomologist

S. C. Chandere, B.S., Southern Field Entomologist

J. H. Bigger, B.S., Central Field Entomologist

I. H. Shropshire, M.S., Northern Field Entomologist

E. R. McGovran, Ph.D., Research Fellow in Entomology

W. E. McCauley, B.S., Assistant Entomologist

J. F. Alsterlund, M.S., Research Fellow in Entomology

\section{SECTION OF APPLIED BOTANY AND} PLANT PATHOLOGY

L. R. Tehon, Ph.D., Botanist

J. C. Carter, Ph.D., Assistant Botanist G. H. Boewe, M.S., Field Botanist

\section{SECTION OF AQUATIC BIOLOGY}

David H. Thompson, Ph.D., Zoologist

F. D. Hunt, Field Naturalist

D. F. Hansen, A.M., Assistant Zoologist

D. J. O'Donnell, M.S., Assistant Z Zologist

\section{SECTION OF INSECT SURVEY}

H. H. Ross, Ph.D., Systematic Entomologist

Carl O. Mohr, Ph.D., Associate Entomologist, Artist

L. H. Townsend, Ph.D., Assistant Entomologist

\section{SECTION OF GAME RESEARCH AND} MANAGEMENT

R. E. Yeatter, Ph.D., Game Specialist

\section{SECTION OF FORESTRY}

L. E. SAWyer, B.S.F., Extension Forester

\section{PUBLICATIONS}

Carroll Chouinard, M.A., Editor 
PART I.-INSECTS ATTACKING THE BARK AND TRUNK OF THE PEACH TREE

San Jose Scale................... 1

Peach Borer....................5

Lesser Peach Borer. . . . . . . . . . . . . . . . 9

Shothole Borer and Peach Tree Bark

Beetle....................... . 10

Terrapin Scale................. 11

PART II.-INSECTS ATTACKING THE TWIGS, FOLIAGE AND FRUIT

Oriental Fruit Moth. . . . . . . . . . . . . . . 12

Peach Twig Borer................ 20

Plum Curculio....................21

Tarnished Plant Bug. . . . . . . . . . . . . . . 29

Stink Bugs... . . . . . . . . . . . . . . . . . 32

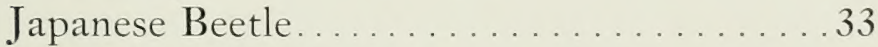

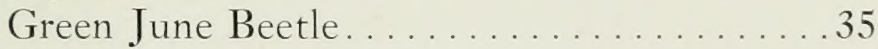

Cotton Leaf Worm Moth. . . . . . . . . . . . . .35

Aphids . . . . . . . . . . . . . . . . 36

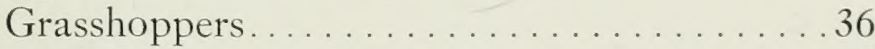

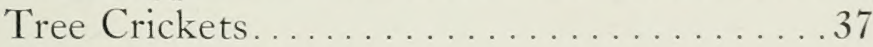

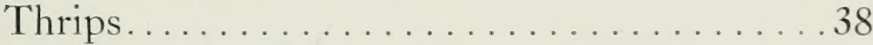



7 HE number of insects attacking the 1 peach is, in common with those infesting other orchard fruits, increasing. Control of them is essential to commercial peach growing in Illinois. This circular discusses 18 of the more common and serious insect enemies of peach, and gives the latest information regarding best known methods of control. 

PART I

\section{INSECTS ATTACKING THE BARK AND TRUNK OF THE PEACH TREE}

\section{SAN JOSE SGALE}

Aspidiotus perniciosus Comst.

APPEARANCE AND TYPE OF INJURY.-A grayish layer of overlapping and very small scales covering the entire bark characterizes a heavy infestation. Rubbing the scales between the fingers produces a greasy sensation and appearance, which comes from crushing the yellow saclike bodies of the insects beneath the scale covering. A light infestation shows as gray or nearly black round specks on the bark, which with the aid of a hand lens show a raised, nipple shaped center. On light colored bark a light infestation is easily detected by a reddish area nearly a quarter inch in diameter around each scale or group of scales.

Under favorable conditions scale infestation may increase seriously, despite our knowledge of methods of control. This was shown by orchard scale surveys on peach and apple, made in southern Illinois in 1930 and 1931. In 1930 only 27 orchards out of 107 examined could be classed as having moderate to severe infestation of San Jose scale, but in 1931 half the 169 orchards examined were in the group of heavily infested trees. The increase of infestation in 1934 over 1933 was even more striking, as appears from the graph, fig. 1 . Two or three years of unrestricted infestation are frequently enough to kill a bearing tree.

controc.-Before the advent of oil sprays in $1922 \mathrm{San}$ Jose scale was much more difficult to control on peach than it is today. Now, however, efficient control may be had by means of these sprays. Lime sulfur at 1 to $\&$ will leave $7-11$ 


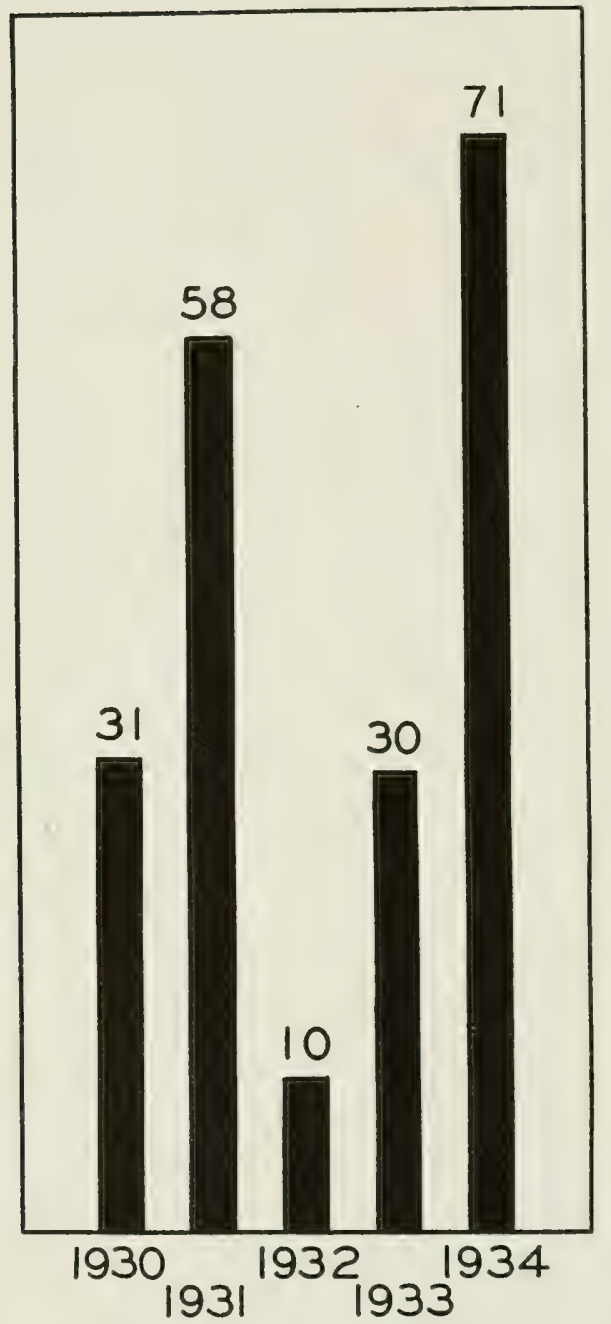

Fig. 1.-San Jose scale survey, showing percentage of peach orchards in Illinois moderately to severely infested. Seventy-five to 100 peach orchards in southern Illinois were inspected each of the years shown. per cent of the insects alive, according to examination of hundreds of thousands of scales in tests conducted in Illinois, whereas oil emulsion or miscible oil sprays at 2 per cent actual oil leave not more than 2 per cent alive. On severe infestation it is advisable to use oil emulsion or miscible oil sprays at $2 \frac{1}{2}-3$ per cent actual oil. Such a spray reduces the number of live scales to 1 per cent or less.

Numerous commercial miscible oils are manufactured, many of which are very efficient when used at the dilutions recommended by the makers.

$$
\text { Leaf curl control.-To }
$$
control leaf curl also, plant pathologists in this and other states have found it necessary to add a fungicide, such as Bordeaux mixture, to the oil sprays. A cold mixed Boreaux oil emulsion can be made by emulsifying the oil in the spray tank. The easiest method is as follows: (See also Illinois Agricultural Experiment Station Circular 4291.)

1"Directions for Spraying Fruits in Illinois," prepared by the University of Illinois department of horticulture and the State Natural History Surver, March 1935. Publication 257. 


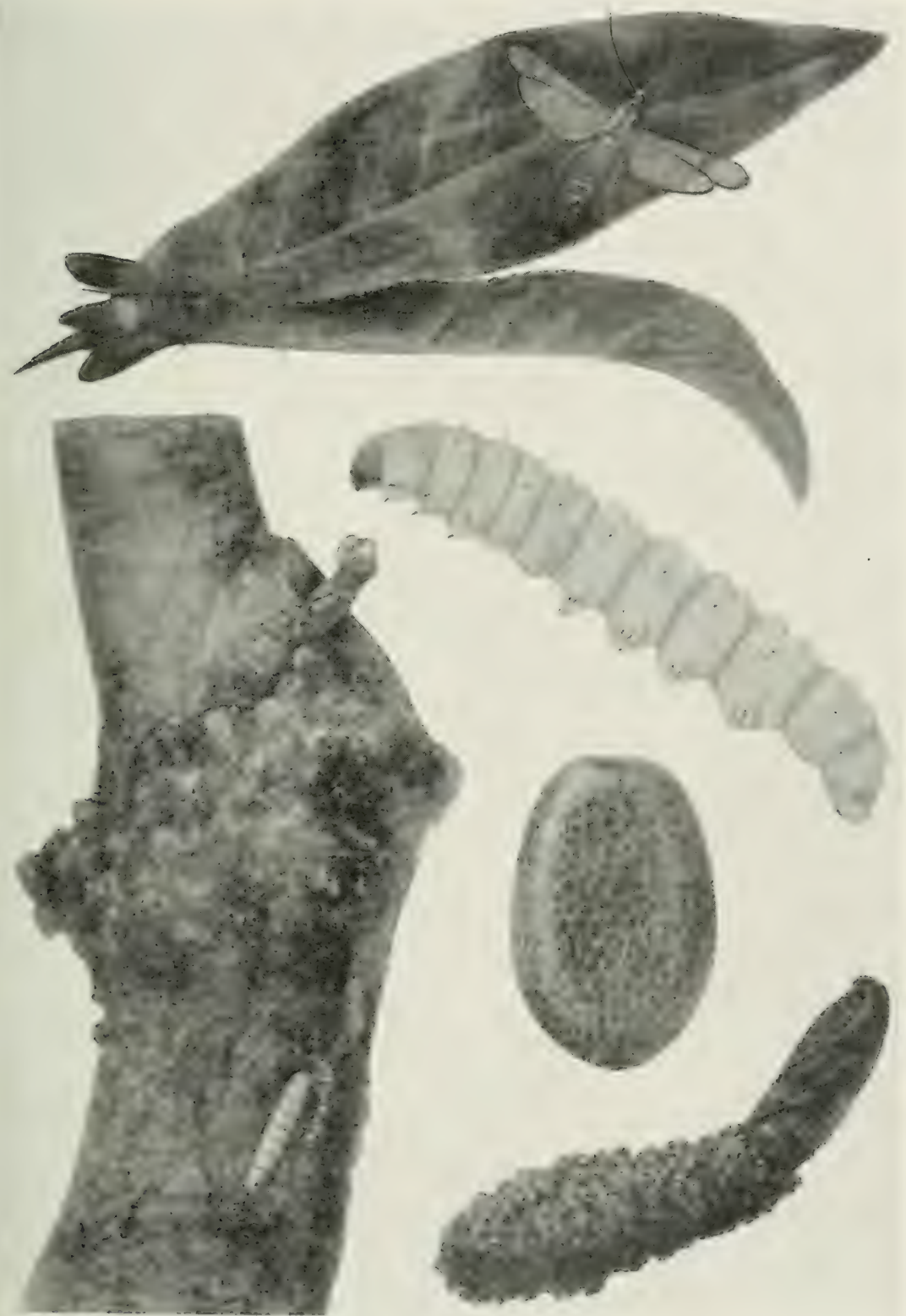

Fig. 2.-The peach borer, Conopia exitiosa Sar. The section of the tree shows the damage wrought by the larva, and frass exuding from the injured trunk. [Courtesy U. S. Bur. Ent.] 
To make 100 gallons of cold mixed Bordeaux oil emulsion, put 25 gallons of water in the spray tank. With the agitator running, sift in 2 pounds of powdered copper sulfate. Put in 2 pounds of hydrated lime previously made in to a paste. This is the Bordeaux mixture. Now pour in 2 gallons of oil and run the pump so that the mixture is pumped back into the spray tank for a few minutes. This is the cold mixed oil emulsion. While the tank is being filled with water, add 6 pounds of copper sulfate and 6 pounds of lime for each 100 gallons of completed spray.

Recently several tar dormant oils containing a fungicide have been put on the American market. The fungicide has cresylic acid or similar material as a base. In our tests to date these oils used at 5 per cent strength show excellent kill of scale, and according to Dr. H. W. Anderson of the University of Illinois department of horticulture, almost completely control leaf curl. As yet they cannot compete in price with oil emulsion Bordeaux.

The liquid lime sulfur at 1 to 7 or 8 , which was the standard spray material for the scale before 1922, has the advantage of being a fungicide and a control for peach leaf curl as well as for light to moderate infestations of San Jose scale. It may be applied either in fall or in the spring before the buds swell much, spring applications haring proved somewhat more effective.

LIFE History.-Only the partly grown San Jose scale lives through the winter, wherein varying temperatures are often a deciding factor in the following year's infestation. Mortality ranges from practically nothing to 98 per cent, according to the severity of winter; $-20^{\circ} \mathrm{F}$ will kill $90-95$ per cent of the scale.

When sap begins to flow in spring the oremintering scales resume development and become fully grown by the time the shucks are being pushed off the peaches. At that time the male scales emerge as tiny yellow two-winged 
insects. The female never moves from under her protective waxy covering, is fertilized by the male soon after his emergence and shortly thereafter gives birth to young.

The young have six legs and are active crawlers, with much the appearance of yellow mites. It is during this active stage, lasting not more than a day or two for each individual, that scale is spread from tree to tree. Larger insects and birds accidentally transport the scales, but most of the spread is due to their being blown by the wind. On finding a place to their liking the crawlers pierce the bark with their threadlike mouthparts and begin sucking the sap. Shortly afterward they shed their skins, lose their antennae and legs, and become to all appearances mere yellow sacs. They exude a waxy substance at first white, then gray, which hardens and forms the scale covering their bodies.

The number of broods in a year depends upon temperature and latitude. Two broods in a year are ordinarily found in northern Illinois and as many as six in the extreme southern end of the state. During mild fall weather crawling young have frequently been observed as late as the middle of November, and in the exceptionally mild autum of 1931 crawlers were observed at Carbondale December 17.

\section{PEACH BORER}

\section{Conopia exitiosa Say}

APPEARANCE AND TYPE OF InJURy.-The peach borer and San Jose scale are the two worst pests of the peach tree itself, and before the use of paradichlorobenzene in modern control practice, the borer was probably the greatest single drawback to commercial growing.

Masses of exuded gum and frass at the base of a tree usually betray the presence of this insect, fig. 2. Examination of the trunk, for several inches abore and below the groundline, of trees so marked, usually reveals the white wormlike borers working in brown areas of the bark or outer wood, which they have deadened by their feeding. 
controu--'The most effective method of controlling the peach borer is by the use of paradichlorobenzene, commonly called PDB. From one-half to 2 ounces of the crystals are used to a tree, according to its age and size. A half-ounce is sufficient for trees 1 full year old, and three-quarters of an ounce is the proper amount for trees $3-5$ years old. The amount for trees more than 5 years old depends upon the circumference of the tree. Tests conducted at Centralia with 15-year old trees, whose circumference was about 21

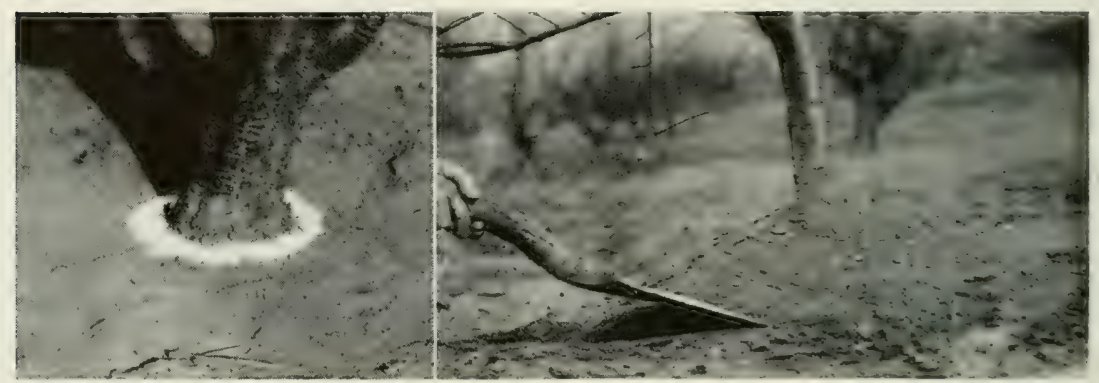

Fig. 3.-Applying PDB for control of the peach borer. a. (Left) - The ring of PDB around the trunk on leveled ground. b. (Right) - Heaping the mound around the base of the treated tree.

inches, demonstrated that 2 ounces of the mixture were required to kill the borers and that three-quarters of an ounce was sufficient on 5-year old trees.

In applying PDB spread a ring of it around the base of the tree trunk not closer than 1 inch nor more than 3 inches away from it, fig. 3a. Cover with four or fire spadefuls of dirt and tamp down with the back of the spade, fig. 3b. It is not necessary to remove moderate grow ths of grass and weeds as they will not interfere with the treatment if the PDB can be placed properly around the tree.

In sandy soils it is sometimes advisable to pull the mounds from the trees two or three weeks after treatment, but in all our tests it has not been found necessary. No harm has been reported from the important peach growing counties of this state where the practice is to leave them. How- 
ever, the mounds should be leveled off by the first week in July, when the moths begin to lay their eggs. If the mounds are not leveled by this time the moths may lay their eggs so high on the tree trunk that the borers will scarcely be reached by the PDB fumes.

When to treat.-The PDB treatment may be applied either in spring or fall. Properly applied fall treatment shows a 95-100 per cent kill as compared with an effectiveness of 80 per cent for spring applications, according to tests conducted at Carbondale for several seasons. In spring it is necessary to wait until ground temperature is about $60^{\circ} \mathrm{F}$ to secure even an 80 per cent kill, which time is usually about May 1 in southern Illinois.

Fall treatment should be applied within a month

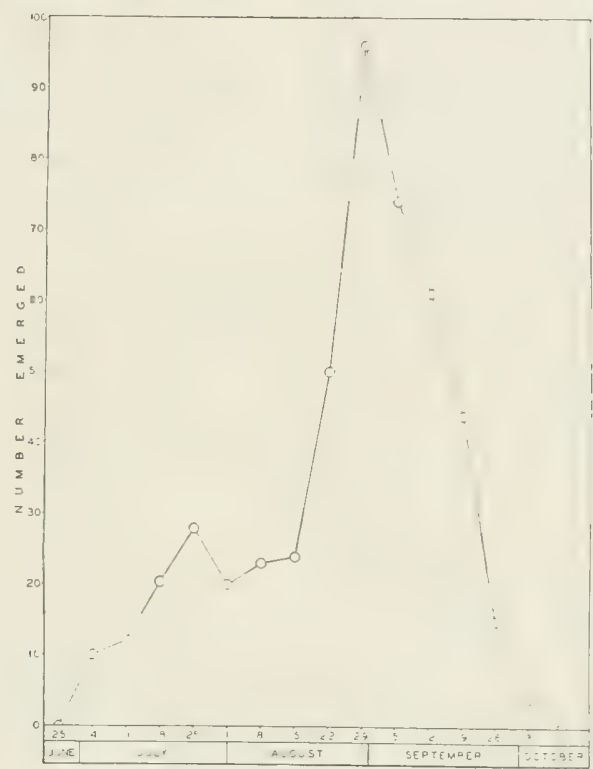

Fig. 4. - Averaged five-year record of peach borer emergence, showing seasonal distribution and the peak of emergence at about September 1. after the moths cease emerging. The peak of emergence for southern Illinois falls between August 29 and September 15, according to a five-year record tabulated by the SuRver, fig. t. In the southern end of the state PDB should be applied from September 25 to October 15, in the CentraliaOlney-Flora district between September 22 and October 10, and in central Illinois from September 20 to October 5. A three-week period after these dates usually occurs during which the soil temperature is high enough to afford maximum results from the treatment.

In the fall of 1934 some tests were started in peach orchards near Carbondale on the use of paradichlorobenzene (PDB) dissolved in oil, applied as liquid around the base 
of the tree for borer control. These tests were of much the same nature as work previously done by Oliver I. Snapp of the U. S. Bureau of Entomology and Plant Quarantine at Fort Valley, Georgia.

In the Illinois work PDB was dissolved in the proportion of 2 pounds to 1 gallon of the following oils: sorbean oil and commercial miscible oils such as "Scalecide" and

Table 1.-Natural History Survey experimentation with PDB dissolved in oils for liquid applications to control peach tree borer.

A. Treatments made October 3-5, 1934, on 6-year old trees

\begin{tabular}{|c|c|c|c|c|}
\hline $\begin{array}{l}\text { Plot } \\
\text { No. }\end{array}$ & Materials Used & $\begin{array}{c}\text { Borers } \\
\text { Alive }\end{array}$ & $\begin{array}{c}\text { Borers } \\
\text { DEAD }\end{array}$ & $\begin{array}{c}\text { PER CENT OF } \\
\text { BorERs } \\
\text { DEAD }\end{array}$ \\
\hline $\begin{array}{l}1 \\
2 \\
3 \\
4\end{array}$ & $\begin{array}{l}\text { PDB in soybean oil............ } \\
\text { "Scalecide" } 1 \text { to } 8 \ldots . \ldots \ldots \ldots \ldots \\
\text { PDB applied in regular manner. } \\
\text { Check-No treatment.......... }\end{array}$ & $\begin{array}{r}2 \\
15 \\
0 \\
27\end{array}$ & $\begin{array}{r}14 \\
1 \\
11 \\
2\end{array}$ & $\begin{array}{r}87 \\
6 \\
100 \\
3.4\end{array}$ \\
\hline
\end{tabular}

B. Treatments made October 22-24, 1934, on 6-year old trees

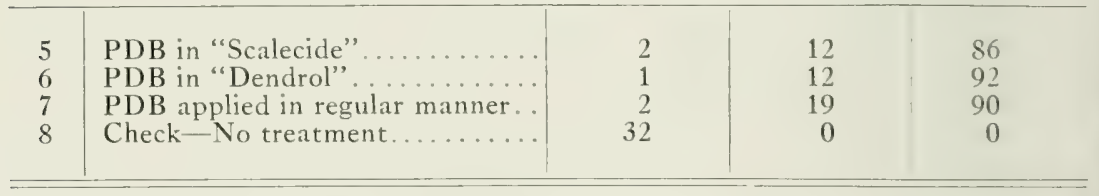

"Dendrol." It was necessary to emulsify the soybean oil with fish-oil soap and water.

At two separate periods in October, 10 trees were treated in each of the plots, which were in two orchards of different ages. Examinations were made after the lapse of intervals sufficient to allow the treatment to work, as determined by ground temperatures. The data are summarized in table 1.

Injury.- At the time of taking data on kill no injury to any trees was shown. Later examinations have shown to date no apparent injury. The observations will be continued.

LIFE History.--The peach borer hibernates in the tree as 
ing the affected areas only with a PDB solution, 1 pound in 2 quarts of cottonseed oil emulsified with fish-oil soap."

It is possible that PDB dissolved in one of the miscible oils and painted on at a strength of 2 ounces to 1 pint of diluted material may prove efficient, as it has in our pre-

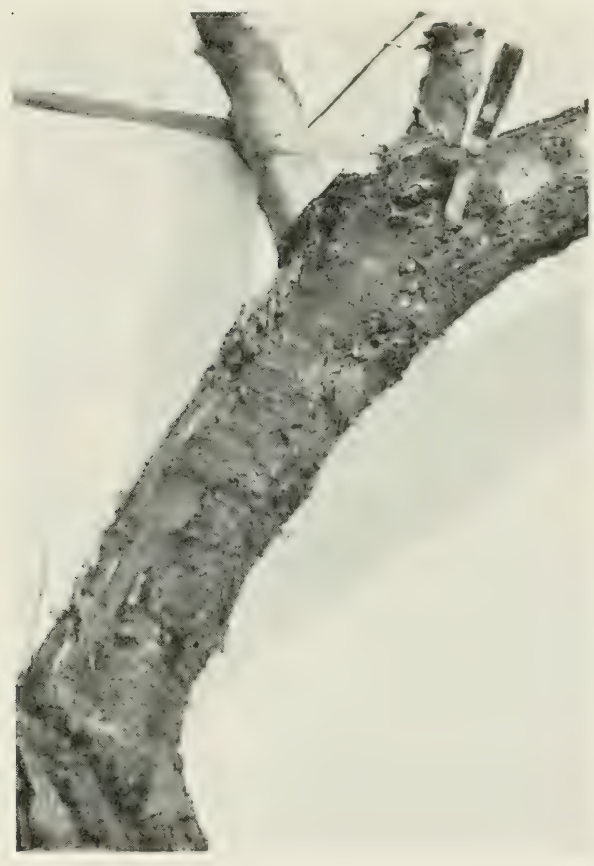

Fig. 6.-Injury caused by larvae of the lesser peach borer, Conopia pictipes G. \& R. This pest works in the crotches and large branches of the tree, especially in areas already injured or weakened.

trol is to keep the trees in good condition. A little extra cultivation or application of fertilizer accomplishes this. All peach prunings or dying and diseased trees should be remored during the dormant season and burned.

LIFE History.-The beetles are brown-black insects about a tenth of an inch long. The larvae are tiny pink-white

${ }^{2}$ "Insects Attacking the Peach in the South and How to Control Them," by O. I. Snapp. U.S. Departmeut of Agriculture Farmers' Bulletin 1557, May 1928. 
footless grubs which make a series of tunnels just beneath the bark, fig. 8. At least two generations occur each year in Illinois.

Fig. 7.-Work of the shothole borer, Scolytus rugulosus Ratz., in peach branches.

TERRAPIN SGALE

Eulecanium nigrofasciatum

Perg.

APPEARANCE AND TYPE OF INJURY.-A brown hemispherical scale less than an eighth of an inch across is occasionally found covering twigs and small branches of peach trees in southern Illinois, figs. 9, 10. In summer leaves and fruit may be covered with sticky honeydew on which grows a sooty black fungus. This scale is usually of little importance but the last few years have witnessed some increase of its numbers in peach regions of the state.

$$
\text { control.-Oil sprays }
$$
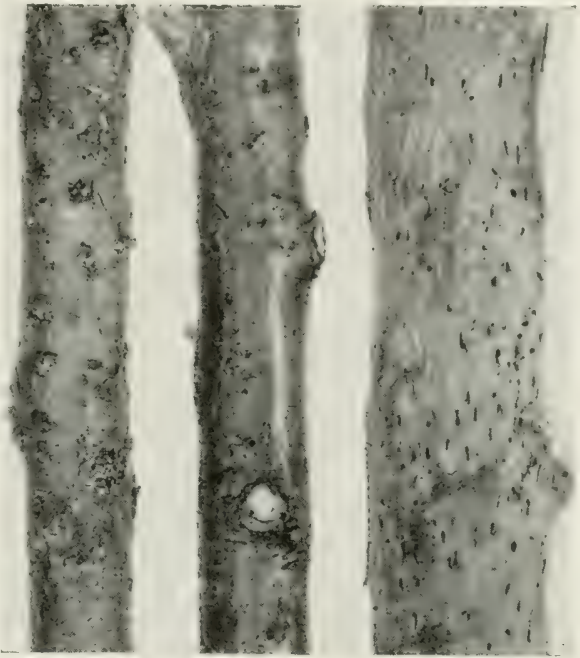

Fig. 8.-Damage by larvae of the peach tree bark beetle, Phthorophlaeus liminaris (Harris), showing characteristic t u n n e ling. [Courtesy U. S. Bur. Ent.] with a strength of at least 4 per cent actual oil applied to the dormant tree are effective for control of this scale. Either miscible oils or oil emulsions, if used at this strength, are satisfactory. Lime sulfur sprays will not control terrapin scale.

uFE HISTORY.-Fertilized females on the bark of small branches and twigs carry the scale over the winter. Feeding is resumed early in spring. In late May or June young

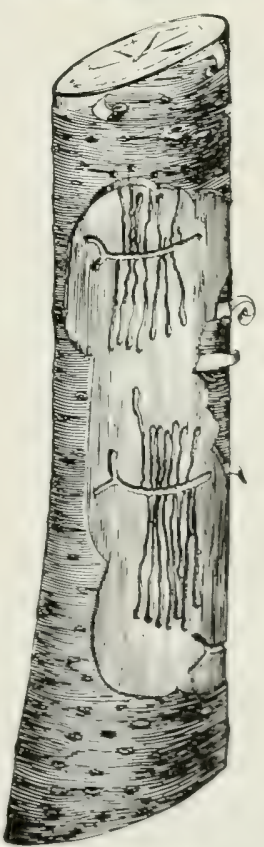
are produced, which one or two days after birth crawl from 
under the female scale to the leaves, where they feed for about a month. At the end of this time the males have matured as two-winged insects and mate with the females, dying soon after. The females continue feeding until cold weather.

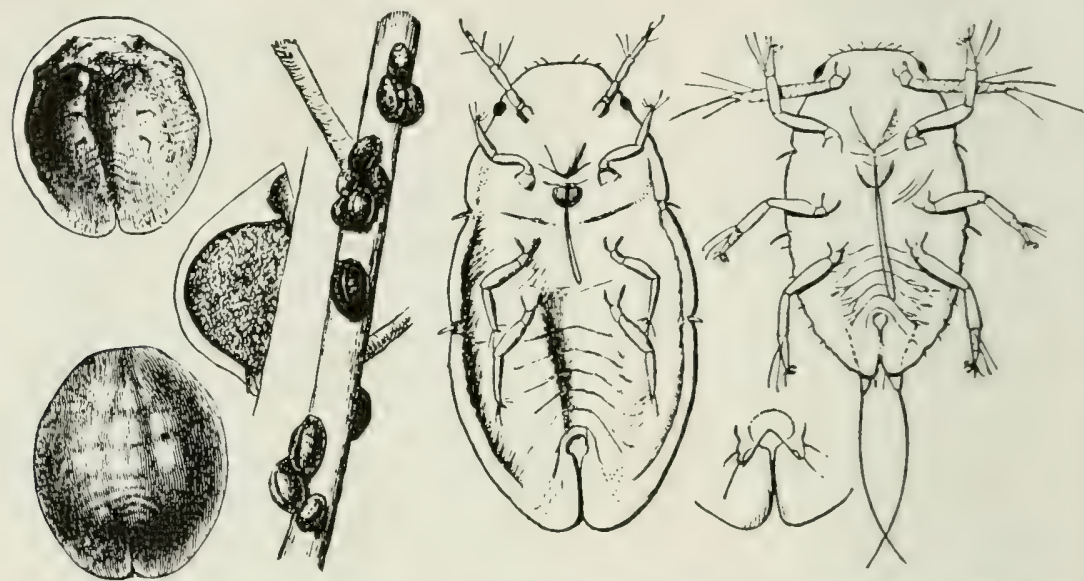

Fig. 9.-Terrapin scale, Eulecanium nigrofasciatum Perg. Adults at left, young at right. Adults 10 times life size. [Courtesy L. S. Bur. Ent.]

PART II

INSECTS ATTACKING THE TINIGS, FOLIAGE AND FRUIT

\section{ORIENTAL FRUIT MOTH \\ Laspeyresia molesta Busek}

APPEARANCE AND TYPE OF INJURY.- The first indication of injury by oriental fruit moth is usually wilting of the young twigs, due to boring of the young worms in terminal shoots, fig. 11. This twig injury has much the same effect as tip pruning as it causes new growths to put out below the point of injury and in extreme cases dwarfs the tree. Injury to the fruit may or may not be seen. Tisible, it appears as brown sawdustlike frass mixed with gum and sometimes a few threads of silk exuding from the peach. This frass usually 
distinguishes oriental fruit moth work from that of plum curculio, in which only gum exudes. Fruit moth larval feeding inside the peach is a little cleaner than that of curculio and is nearly dry with some webbing usually present, fig. 12.

Relative importance of oriental fruit moth among pests of Illinois peaches is not yet known. On late varieties such as Krummel's October and Heath cling, infestations up to 50 per cent or more have been noted. On Elbertas and Hales, which constitute 95 per cent of the peach crop of the state, infestation had reached not quite a third by 1931 , whereas in eastern states it had affected one half to three fourths of the crop within two years after discovery.

In Illinois the insect was first found in Pulaski county in the fall of 1927. Twenty-nine per cent was the highest infestation in a Pulaski county orchard in 1929 and 22 per cent was the high mark for 1931, but averages for the county in both years were considerably less. In the light crop of 1932 as

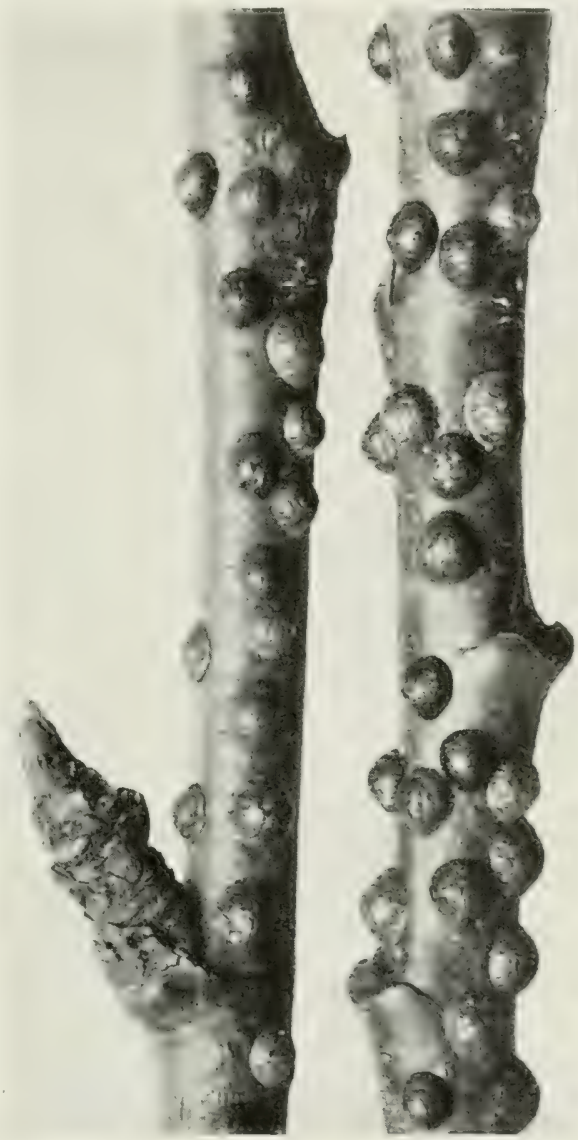

Fig. 10.-Twigs of peach tree bearing many adults of terrapin scale. About six times life size. [Courtes: U. S. Bur. Ent.] high as 40 per cent infestation was counted in our experimental plots, but in 1933 the maximum was much less. The insect has now spread to all peach sections of the state. Infestation will probably be much more uniform over the state the next few years. 


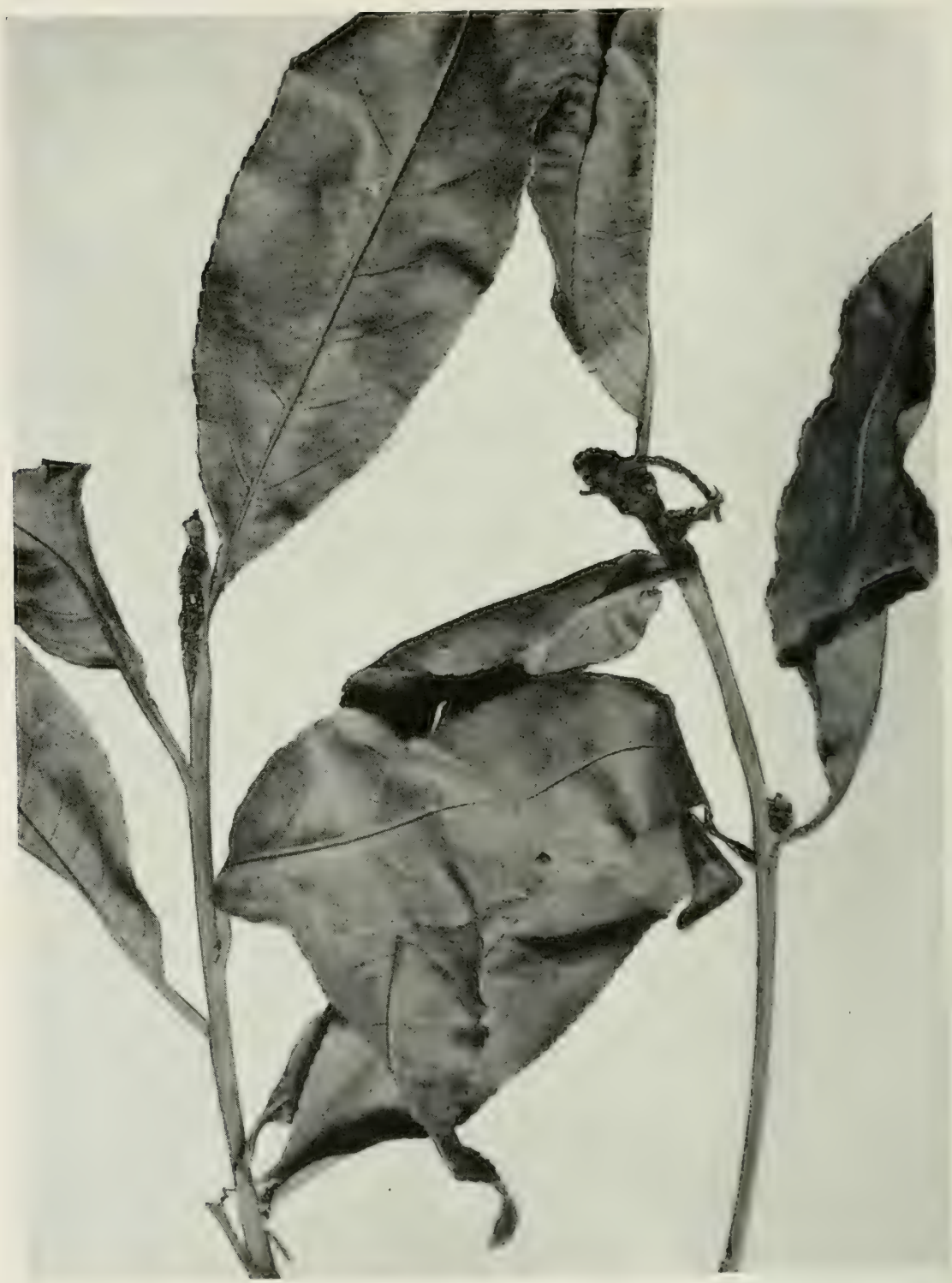

Fig. 11. - Injury to twigs of the peach tree by the burrowing larvae of oriental fruit moth, Laspeyresia molesta Busek.

control.--(a) By parasites.-Since introduction of parasitic control in the Inited States in 1912, notable reductions in infestation have been achieved in several eastern states. 
Of the 40 or more parasites attacking the oriental fruit moth, two are of greatest importance, one a parasite of the egg, called Trichogramma mimutum Riley, and the other a parasite of the larva, Macrocentrus ancylivora Roh. Liberations of the larval parasite have been made in almost every peach growing county of the state, with the cooperation of Dr. H. IV. Allen of the U. S. Bureau of Entomology. Because of the total absence of peaches in 1930 and the extremely light infestation of oriental fruit moth in 1931, conditions have not been very favorable for recovery collections, for the purpose of determining to what extent the parasite has become established. However, on August 7, 1933, Dr. Allen reported a 35 per cent parasitism from one collection from Villa Ridge, where $M a-$ crocentrus ancylivora

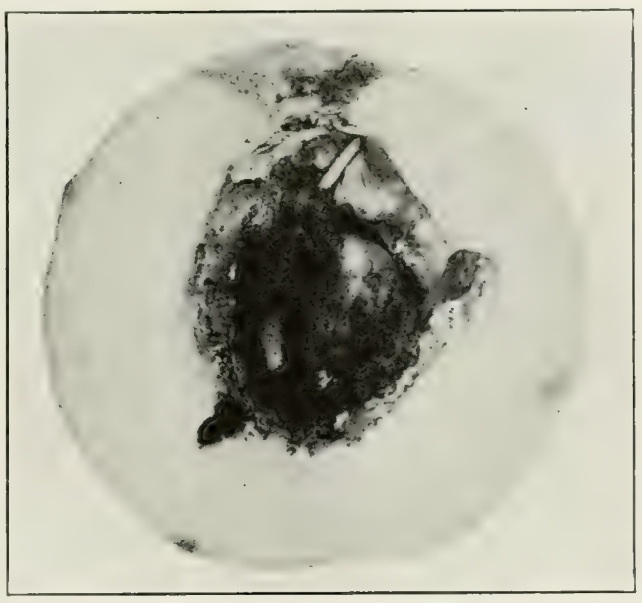

Fig. 12.-Cross section of peach showing injury to the fruit by larvae of oriental fruit moth. About life size. [Courtesy Purdue Univ. Agr. Exp. Sta.] had been liberated. In 1934 two orchards in Pulaski county showed 40 and 50 per cent parasitism, respectively. The egg parasite has been reared in the Natural History SLRIEY laboratory at Urbana and liberated in considerable numbers throughout orchard sections of Illinois.

(b) By sprays and dusts.-Due to the larva's habit of ejecting all the material it bites out in boring in to the twigs or fruit, the arsenical poison in the usual sprays is of no value, and control measures based upon entirely different principles must be developed. To date the two most promising lines of attack are the use of an oil spray in combination with lime, talc and sulfur, and the use of oil dusts. Concerning these materials no very definite recommendations 
can yet be made, but our experience to date leads us to favor the oil dust where the grower is equipped for it. Kill is partly due to destruction of the eggs but chiefly to poisoning which the tiny larvae contract by crawling over the leaves and fruit covered with oil and oil dust. In almost every case where as many as six liquid applications have been given in our experiments there has been a marked reduction in infestation compared to the check plot, even in those blocks which were sprayed only with lead arsenate, or lime sulfur for curculio, peach scab and brown rot. The most effective period for the application of sprays and dusts is probably the latter part of the season, starting a month before harvest.

Dust for oriental fruit moth control during the period three weeks before harvest should not contain lead arsenate but per 100 pounds have the following formula.

60 lbs. dusting sulfur

35 lbs. dusting lime

5 lbs. lubricating oil of $80-110$ viscosity.

There is a slight improvement in the dust if 300 mesh talc is used in place of half the lime. The ingredients must be thoroughly mixed in a dust mixer. Simply stirring the materials together will not make a satisfactory oil dust.

In the one season of 1929, when we had opportunity to use oil dusts under conditions of a sufficient crop and heary infestation, they showed 80 per cent control, based on chech blocks showing 25 per cent infestation. The following year practically as good results were obtained by experimenters in New York state. One of the best dusts used so far contains by weight 60 per cent sulfur, 35 per cent lime and 5 per cent straw oil. Ten per cent of lead arsenate may be substituted for the same amount of lime when the dust is used for plum curculio. As the oil dust costs but little more than the common 80-10-10 dust and contains all the ingredients for curculio and brown rot control, it is worthy of trial by orchardists. At the present time we believe that 
1 pound of oil dust should be applied to each tree 10 years old or older, and that for the applications in the latter part of the season at least three oil dusts should be given, starting one month before harvest and ending within five or six days of the first picking.

For best results care must be taken in applying the treatment. Dusting only one side of the rows of trees and expecting the wind to carry the dust through to the other side will produce poor results. The orchardist should apply the dust to both sides of each tree to get full benefit of the operation.

(c) Supplementary control measures.-Several supplementary control measures of little or unknown value are discussed here because of frequent queries about them. In the seasonal order in which the orchardist might undertake them they are:

1.-Early cultivation. This has been a standard recommendation in eastern states and if any appreciable percentage of our peaches were late varieties it would be worth while in this state. Very careful hibernation studies since introduction of the insect into Illinois have shown very few worms carried over the winter in Elberta or Hale orchards, and the proportion of larvae wintering on the ground is insufficient to warrant the expense of cultivation. This is especially true since cultivation would have to be done by petal fall, which if not impossible is often inadvisable in the hill lands of this state.

2.-COLlECTION AND BURNING OF INFESTED TIVIGS. This operation has been found to be of very little value in reducing infestation, chiefly because it is very difficult to find all the newly entered twigs.

3.-Banding. This is possibly of some value on late maturing peach trees but not on Elbertas or earlier varieties. An average of larvae as high as 150 to a tree has been caught in our banding tests on Krummel's October trees. 
4.- USE OF PDB. Tests conducted in 1929 showed a kill by PDB of 70-90 per cent of the oriental fruit moth larvae hibernating about the base of trees of late varieties. Hibernation studies, however, indicate that not more than 21 per cent of the larvae hibernate in the area reached by the gas, and considering the small amount of fruit moth hibernation in Elberta orchards this treatment is profitable only for its simultaneous control of peach tree borer.

Table 2.-Situations of wintering oriental fruit moth larvae. The figures are percentages of 1,000 cocoons found in each situation.

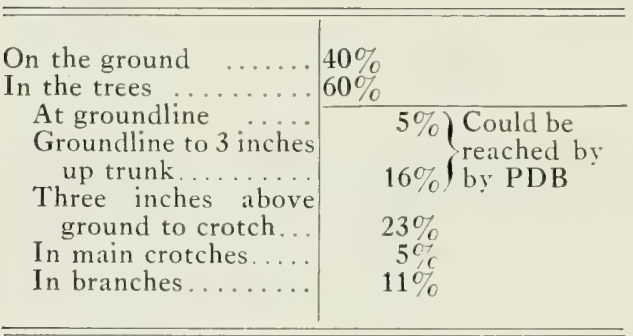

5. -BAIT TRAPPING. Adultoriental fruit moths are strongly attracted to certain odors, a long series of tests carried on mainly by Yetter and Steiner of the federal Bureau of Entomology, reveals. Attempts have been made to control the moths by trapping them in pails or jars of scented liquids hung on the trees. In two of the larger experiments 30,000 to 50,000 bait jars were used and many hundreds of thousands of moths were caught. While it is certainly possible to catch large numbers of moths in bait pails, it has not yet been demonstrated that bait trapping them is profitable from a commercial standpoint.

6.-REMOVAI OF late maturing PEACH TREes. Most Elberta and Hale peach orchards contain a few late maturing trees, such as Heath cling and Krummel's October or late seedlings, which are of very little commercial value to the owner and are left for home use or local trade. Our hibernation studies show 50-150 times as many larrae wintering on or under such trees as on Elbertas, and it is good policy to remove these late maturing trees.

7.- Removing hale "Buttons." For the same reason that later maturing varieties of peach become more infested, 
the late crop of small fruit on the Hale variety, called "buttons," is usually infested to a greater extent than is the main crop. Often these late misshapen fruits are left on the tree, and on two occasions we have noted that infestation was greater the following year in that part of the orchard where these fruits were left than it was where they were picked. For this reason we advise the removal of these fruits as soon after the regular crop as possible.

LIFE HISTORY.-The oriental fruit moth passes the winter as a full grown larva about a half-inch long, in a cocoon attached to some part of the tree or on the ground under the branches. In the winters of 1928-29 and 1929-30 studies were made to determine the percentage of worms

Table 3.-Comparison of early and late varieties of peach trees as hosts of wintering oriental fruit moth larvae.

\begin{tabular}{c|c|c}
\hline Kind & $\begin{array}{c}\text { No. } \\
\text { TREES } \\
\text { ExAMINED }\end{array}$ & $\begin{array}{c}\text { No. } \\
\text { LARVAE } \\
\text { Found }\end{array}$ \\
\hline Late maturing trees .... & 14 & $\begin{array}{l}967 \text { (tree } \\
\text { and ground } \\
\text { beneath) } \\
\text { Eltree and } \\
\text { ground be- } \\
\text { neath) }\end{array}$ \\
$\begin{array}{l}\text { Elberta and Hales (show- } \\
\text { ing post harvest twig } \\
\text { infestation, } 75 \% \text { of tips } \\
\text { injured) ............. }\end{array}$ & 40 & \pm (treeonly) \\
\hline \hline
\end{tabular}
hibernating in different situations. Approximately 1,000 larvae were found and their locations recorded. Tables 2 and 3 summarize the findings.

Larvae of the oriental fruit moth are pinkish yellow, about a half-inch long, very active, and will drop suspended from a silk thread if disturbed when crawling about. Peach twig borer larvae are not to be confused with those of the oriental fruit moth; the former are chocolate brown with body segments well defined, giving a ringed appearance.

In the spring, larvae of the fruit moth change to the pupal stage at or before full bloom, and small brown or grayish moths emerge. The eggs are about half the size of a pin head, white and flattened. They are laid chiefly on under sides of leaves near the tips. On hatching, the larrae of the 
first and second broods bore into the young twigs. Third brood larvae feed largely in the fruit, and fourth and fifth broods occur in the southern part of the state on apple, quince, pear and late varieties of peach.

\section{PEACH TWIG BORER}

Anarsia lineatella Zell.

APPEARANCE AND TYPE OF INJURY.- The peach twig borer is chiefly a pest of unsprayed orchards. Only once in the past 15 years (1930) has it become abundant in commercial

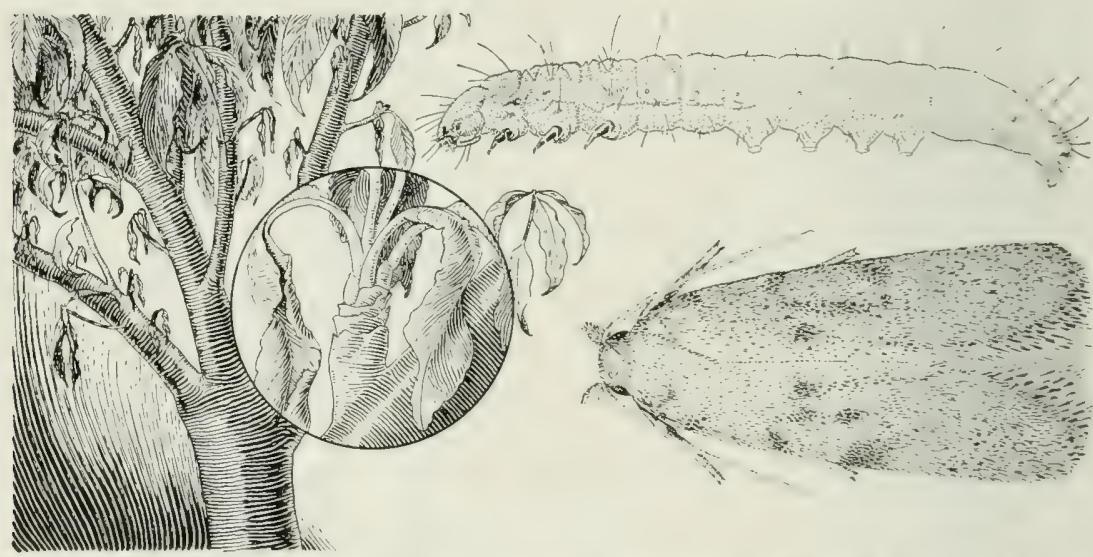

Fig. 13. - The peach twig borer, Anarsia lineatella Zell. Eight times life size. Inset, wilting condition of twigs injured by larvae, which attack the tender shoots and cause injury resembling that produced hy oriental fruit moth.

plantings, and then very little damage was done. This borer causes an injury similar to that of the twig boring oriental fruit moth, but the work of the two pests may be distinguished on at least two counts. The twig borer is active before the oriental fruit moth, as we judge from the 1930 infestatation, boring into the tough wood of the tree as soon as the first leaves appear, fig. 13. The oriental fruit moth is not active until the trees have new growths $2-4$ inches long. Then it attacks only the more tender twigs.

control.-Standard dormant tree sprays of sulfur or oils for the control of San Jose scale are equally effective against 
the twig borer. In California, where the insect is more important, orchardists find some advantage in waiting until it has nearly reached the pink stage and then add lead arsenate, 6 pounds to 100 gallons, to the sprays.
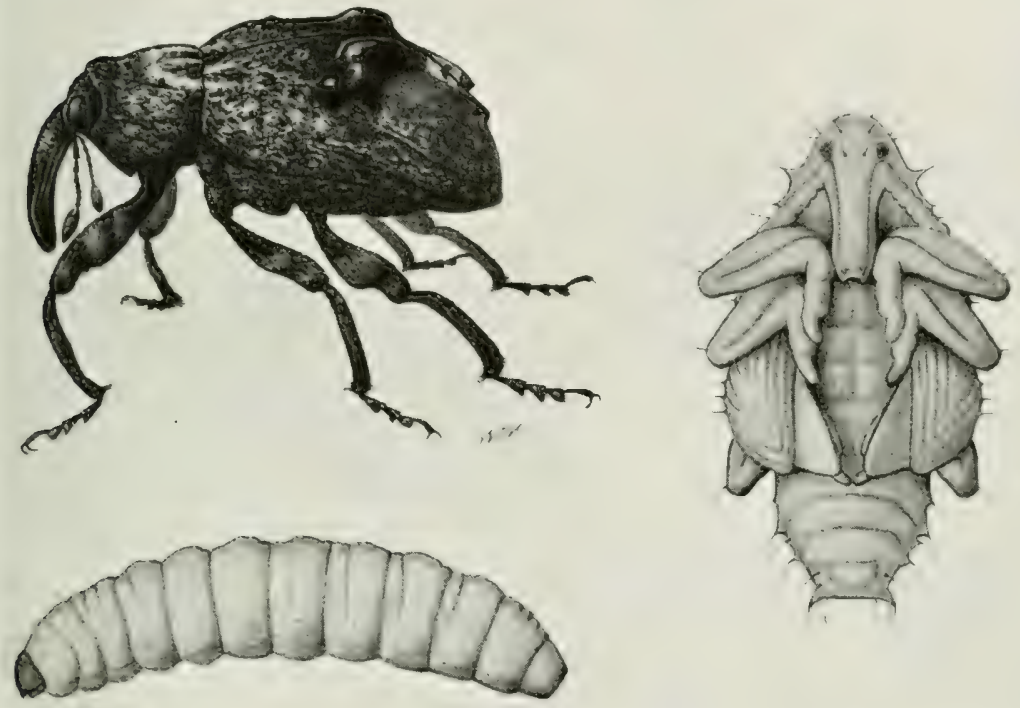

Fig. 14. - The plum curculio, Conotrachelus nemuphar (Hbst.). Adult, upper left; larva, below; and pupa, right. Nine times life size.

LIFE HISTORY.-The partly grown, reddish brown larva, one-eighth inch long, passes the winter in a silken case on the trunk of the tree. It is easy to kill in this case with a lime sulfur or oil spray. Leaving this shelter to attack the tree about the time first leaves appear, the larva by its feeding causes the new twigs to wilt and die back to the old growth. The larval form attains a length of one-half inch with segments of the body well marked. Two generations of the insect occur each season in Illinois.

\section{PLUM GURGULIO}

Conotrachelus nemuphar (Hbst.)

appearance and type of injury.-The plum curculio, fig. 14 , 
which also attacks cherry, apricot, plum and apple, is one of the most destructive pests of the peach fruit. Wormy fruit due to curculio is usually evidenced by gum or wax on the outside of the peach. Presence of the insect may be detected by early drop of small peaches, premature ripening and drop shortly before harvest.

Two other types of injury are prominent. Punctures on the fruit made by the insect in feeding and egg laying de-

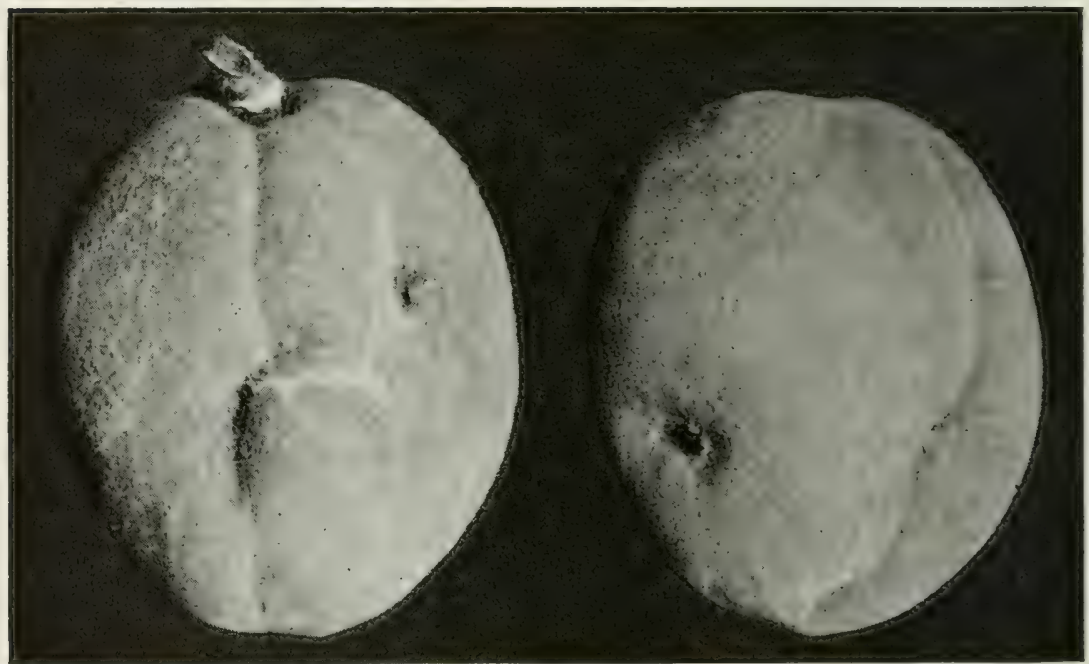

Fig. 15. - Injury to fruit by adult plum curculio.

velop into brown rot, which is always severe when curculio is abundant. Catfacing, the major proportion of which is usually attributed to the tarnished plant bug, is nevertheless caused in some as yet undetermined amount by the plum curculio insect. This injury appears as scarred places on the fruit where the beetles have fed early in the season, fig. 15.

controu.-The peach grower must rely chiefly on spraying or dusting for control of plum curculio, spraying during the growing season principally for control of curculio and brown rot, and thereby greatly adding to his expense.

Illinois Agricultural Experiment Station Circular 4293

${ }^{3}$ See footnote, p. 2. 
gives a complete spray schedule, including that for insects and diseases of peach, combined. For curculio the sprays should contain 3 pounds of lead arsenate for every 100 gallons of spray, except in the last application, when it is reduced to 2 pounds because of possible residue, or 5-10 pounds of lead arsenate in every 100 pounds of dust. The mixtures should be applied at the following times during the season.

1.-At that period in shuck fall when most of the shucks are half off the fruit.

2.- Ten days after the first application.

3.-Two to three weeks following second application.

4.-One month before harvest.

An additional spray is often applied in severe curculio years between Nos. 3 and 4 in the above schedule.

To determine the time when curculios are feeding on peaches in southern Illinois and consequently the best time to spray, a series of jarring collections begun at Carbondale, Illinois, in 1925 has been continued to the present. Natural occurrence of the insect was determined by making the collections in unsprayed peach orchards. Ten trees were taken as a unit and jarred every few mornings throughout the season. The curculios were allowed to fall on sheets and were released after being counted so as not to interfere with their natural activities in the orchard. Every season since 1928 sprayed trees have also been jarred. The records, part of which are shown in fig. 16, disclose that

1.- Shuck fall is early enough for a first application of spray or dust; a petal fall application thought necessary in some peach growing sections is not needed in Illinois.

2.-Applications at shuck fall and 10 days later are the most important of the season, and are all that are needed in years of light curculio infestation.

3.-Later sprays are of greater importance in years of heavy infestation, as in 1928 and 1929. Table 4 and fig. 16 show the need which arose in 1929 of including lead arsenate in the application one month before harvest. In that year more curculios 
were found in both sprayed and unsprayed orchards two to four weeks before harvest than at any other time.

4.-Occurrence on peach practically ceases by harvest and attempts to poison them after harvest are usually not worth while. In a year of a general light crop when curculios might be concentrated in a small block which bore some fruit, post season spraying might be advisable in that block. Our jarrings in 1932 showed such a condition in a small block of Hale peaches in which Hale "buttons" were allowed to remain on the trees.

\begin{tabular}{|c|c|c|c|}
\hline & 1928 & 1929 & 1931 \\
\hline \multicolumn{2}{|l|}{$M A R C H$} & 31 & \\
\hline \multicolumn{2}{|c|}{$\begin{array}{r}\text { A PRIL } 2 \\
3 \\
24 \\
26= \\
29= \\
\end{array}$} & $\begin{array}{l}6= \\
13 \\
21=1 \\
29=0\end{array}$ & $\begin{array}{l}15= \\
17 \\
20 \\
28=\mathbf{m} \\
30=\mathbf{m}\end{array}$ \\
\hline MAY & 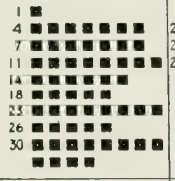 & $\begin{array}{l}7 \\
20 \\
23 \\
27 \\
=0=\end{array}$ & $\begin{array}{l}5= \\
9 \\
14 \\
19 \\
23 \\
28\end{array}$ \\
\hline JUNE & 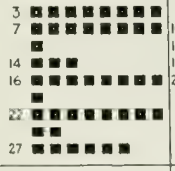 & 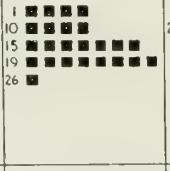 & ${ }_{21}^{41}$ \\
\hline JULr & 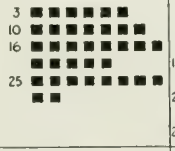 & 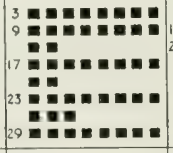 & $\begin{array}{l}7 \\
15 \\
27 \\
\end{array}$ \\
\hline AUGUST & $\begin{array}{l}30=0 \\
10=0 \\
16 \\
28\end{array}$ & $\begin{array}{l}5= \pm \\
10=0 \\
16 \\
26=\end{array}$ & ${ }_{27}^{8}=$ \\
\hline SEPTEM & BEER R & 4 & 14 \\
\hline OCTOBEF & & & 2 \\
\hline
\end{tabular}

Fig. 16.-Graph of plum curculio infestation. The squares show the number of adult curculios jarred from 10 unsprayed trees in various orchards of southern Illinois for three years on each of the dates given. In years of light infestation, such as 1931, the first few sprays are normally sufficient.
Too much lead arsenate in the sprays will result in arsenical injury to the trees. Roughening of the bark may be produced, which is usually accompanied on the younger twigs by exudation of gum around the axil of the leaf or fruit. On foliage the injury may have a shothole appearance or partial defoliation may result, figs. 17, 18. Cooperative tests with the department of horticulture of the University of Illinois disclose that the use of zinc Bordeaux as recommended for bacterial spot greatly reduces injury from lead arsenate, that application of twice as much hydrated lime as lead is necessary to avoid injury, and that injury may occur under certain weather conditions in the face of these precautions.

Dusts have given farly satisfactory results where used frequently. In the proportion of $s 0$ pounds sulfur, 10 


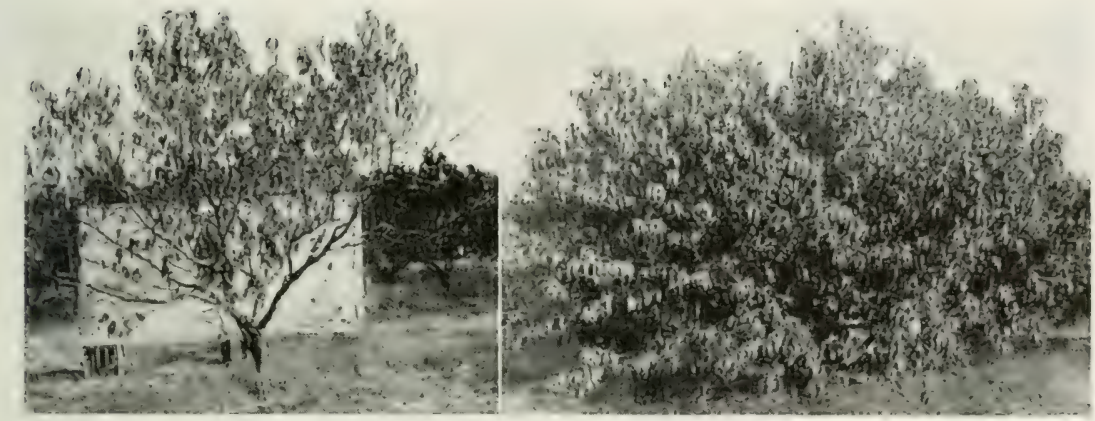

Fig. 17.-Oil dusts vs. lead arsenate without lime. a. (Left)Peach tree sprayed throughout one season (six applications) with lead arsenate without lime, showing severe defoliation and serious injury to the twigs and branches. b. (Right) - Peach tree from adjoining row treated throughout the season (six applications) with oil dusts. The foliage shows no injury of any sort.
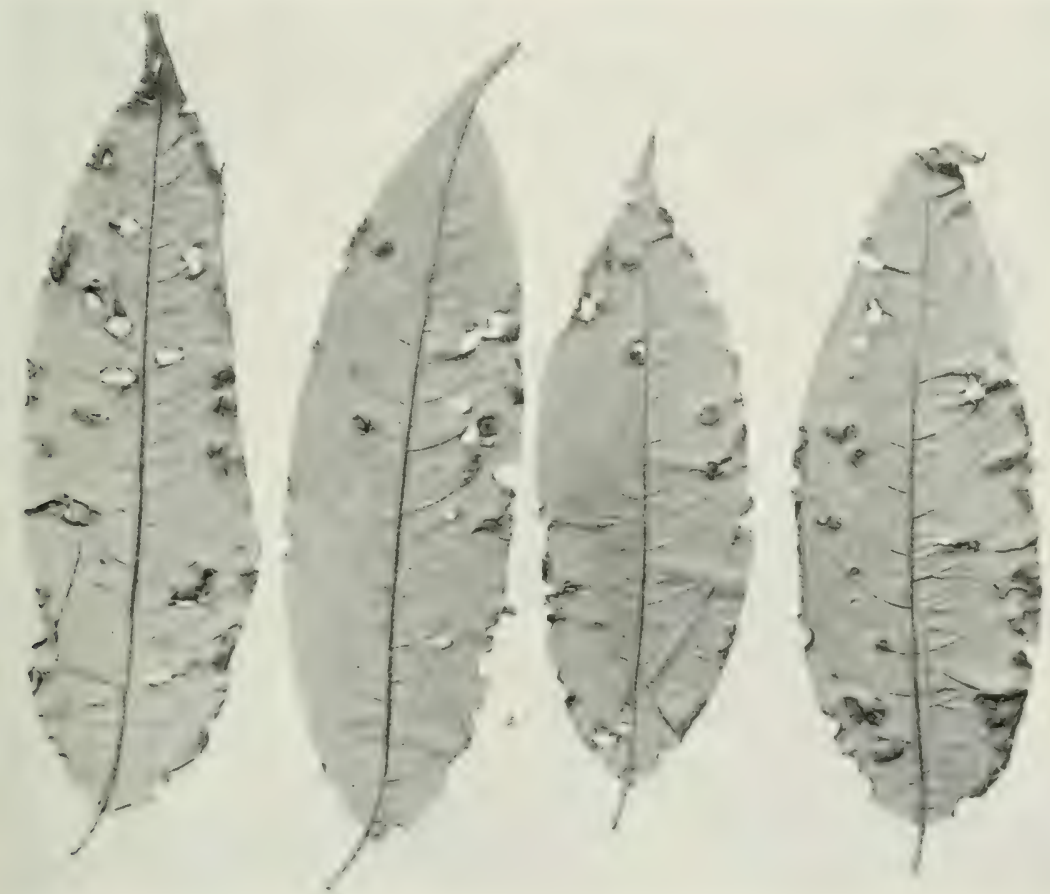

Fig. 18. - Typical injury to leares caused by lead arsenate spray. 
pounds hydrated lime and 10 pounds lead arsenate, dusts used on the regular schedule have never given as good results as have sprays in our experiments in years of moderate to severe infestation.

Oil dusts containing 5 per cent oil by weight, developed in the course of Illinois work on control of oriental fruit moth, have in three seasons given good control of plum curculio, as shown in table 4 .

Table 4.-Control of plum curculio by oil dusts.

\begin{tabular}{|c|c|c|c|c|c|c|c|}
\hline \multirow[b]{2}{*}{ YEAR } & \multirow[b]{2}{*}{ Location } & \multirow[b]{2}{*}{$\begin{array}{c}\text { PEACHES } \\
\text { EX- } \\
\text { AMINED }\end{array}$} & \multicolumn{5}{|c|}{$\begin{array}{l}\text { Percentage of Infestation in Sprayed and } \\
\text { Check Block (Unsprayed) Areas }\end{array}$} \\
\hline & & & $\begin{array}{c}1 \\
\text { Oil } \\
\text { dust } 5 \%\end{array}$ & $\begin{array}{c}2 \\
\text { Standard } \\
\text { dust } \\
80-10-10\end{array}$ & $\mid \begin{array}{c}3 \\
\left|\begin{array}{c}\text { Standard } \\
\text { spray }\end{array}\right|\end{array}$ & $\begin{array}{c}4 \\
\text { Check } \\
\text { block } \\
\text { No. } 1\end{array}$ & $\begin{array}{c}5 \\
\text { Check } \\
\text { block } \\
\text { No. } 2\end{array}$ \\
\hline 1929 & $\begin{array}{l}\text { Graves orchard... } \\
\text { Pulaski county }\end{array}$ & 1,000 & 5. & 10.1 & 2.3 & 31.3 & 25.4 \\
\hline 1931 & $\begin{array}{l}\text { Chandler orchard.. } \\
\text { Jackson county }\end{array}$ & 2,000 & .2 & .1 & .1 & 8.8 & \\
\hline 1932 & $\begin{array}{l}\text { Thomas orchard.. } \\
\text { Jackson county }\end{array}$ & 2,000 & 2.7 & & 2.5 & $2+.8$ & \\
\hline 1932 & $\begin{array}{l}\text { Chandler orchard.. } \\
\text { Jackson county }\end{array}$ & 2,000 & 4.8 & & 7. & 15.8 & \\
\hline
\end{tabular}

One of the best dusts for use on peaches for the control of curculio is made by thoroughly mixing the following ingredients:

60 lbs. dusting sulfur

25 lbs. dusting lime

10 lbs. lead arsenate

5 lbs. lubricating oil of $80-100$ viscosity.

For half the lime 300 mesh tale may be substituted for the sake of a slight improvement in the dust.

Supplementary control measures. 1. -WINTER CLEAN-UP, including general orchard sanitation.

2.-PICK-UP OF DROPS. We have regularly found early drops 50-90 per cent wormy; with low labor cost it may be profitable to pick them up when infestation is severe. The first pick-up should be made about one month after bloom, 
and two or three additional collections at intervals of five or six days. The drop peaches should be burned or buried 2 feet deep.

3.-Cultivation. Late spring and early summer cultivation destroys larvae and pupae in the cells in the ground.

LIFE HISTORY.- The adult insect is a dark brown beetle about a quarter-inch long, with four small humps on its wing covers, fig. 14. Its mouthparts are at the end of a

Table 5. Emergence of plum curculio from drop peaches.

\begin{tabular}{|c|c|c|c|}
\hline$Y_{E A R}$ & $\begin{array}{l}\text { WORMY DROPS } \\
\text { IN CAGES }\end{array}$ & $\begin{array}{l}\text { No. of Plum } \\
\text { Curculio } \\
\text { Emerged }\end{array}$ & $\begin{array}{c}\text { Percentage of } \\
\text { Plum Curculio } \\
\text { Emerged }\end{array}$ \\
\hline $\begin{array}{l}1925 \ldots \ldots \ldots \\
1926 \ldots \ldots \\
1927 \ldots \ldots \\
1928 \ldots \ldots \\
1929 \ldots \ldots \\
1930 \text {. . . . . . . . . . . . . . . . . . . . . . . . . . . . . . . . . . . . } \\
1931 . \\
1932 \ldots \\
1933 \ldots\end{array}$ & $\begin{array}{l}1,700 \\
2,100 \\
2,000 \\
3,000 \\
8,000 \\
4,000 \\
1,550 \\
2,000 \\
1,600\end{array}$ & $\begin{array}{r}15 \\
13 \\
69 \\
33 \\
564 \\
16 \\
35 \\
420 \\
165\end{array}$ & $\begin{array}{r}.9 \\
.6 \\
3.4 \\
1.1 \\
7 . \\
.4 \\
2.2 \\
21 . \\
9 .\end{array}$ \\
\hline
\end{tabular}

trunklike snout which is nearly a third as long as the body. The adult passes the winter in brush piles, fence rows, the edges of woods and similar situations, and emerges in spring. At or a little before shuck fall the female cuts a crescent shaped slit in the young peach or apple, plum or apricot, in which it lays a single egg. A white footless grub hatches from this egg and feeds on the pulp of the fruit. The infested fruit usually drops in the course of two or three weeks; the larvae then leave it to burrow two or three inches into the ground. Here they excavate cells in which to pass the pupal or resting stage. From these pupae the next brood of beetles emerges, beginning the first part of July and continuing into August. The emerging beetles feed on the peaches and then go into hibernation, to reappear the next year. Under favorable circumstances, however, a second brood may occur the same year in southern Illinois. In 1927 
a few individuals of a second brood, which began to emerge in August after peach picking, were reared. In 1933 a few individuals were again reared, beetles emerging in September. These repeated attempts with little results would seem to indicate that the second brood is of little importance in Illinois.

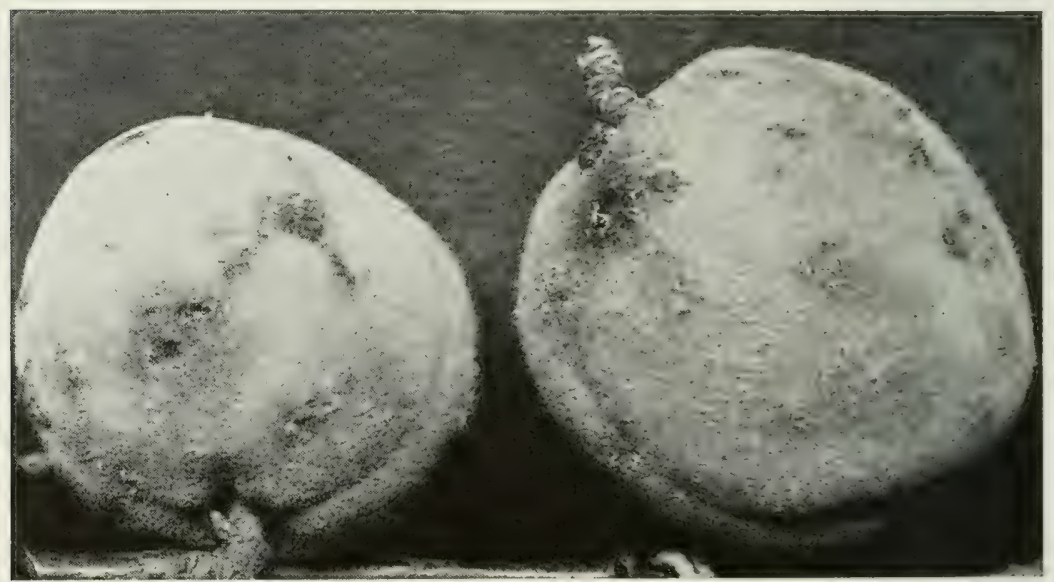

Fig. 19.- - Injury to fruit caused by adult tarnished plant bug, Lygus pratensis (L.).

Moisture largely determines the extent of emergence from the pupal stage. Table 5 records emergence experiments in which 2,000 to 8,000 wormy drop peaches were placed each year in screened cages sunk in the ground under the branches of orchard trees. The dates and number of beetles emerging were recorded; as the table shows there was a heavy emergence in the wet year 1929 and a very slight one in the drouth year 19.30, with a return to approximate normal in 1931. The rainfall in 19.32, while not excessive, was very evenly distributed during the period most important to the insect. In $19,3.3$ excessive rainfall occurred early until the middle of May, after which the rest of the year was exceedingly dry. There appeared to be sufficient hold-over effect of the early moisture to allow a considerable percentage of emergence. 


\section{TARNISHED PLANT BUG}

Lygus pratensis (L.)

APPEARANCE AND TYPE OF INJURY.--The tarnished plant bug, although considered a minor pest, often damages as much as

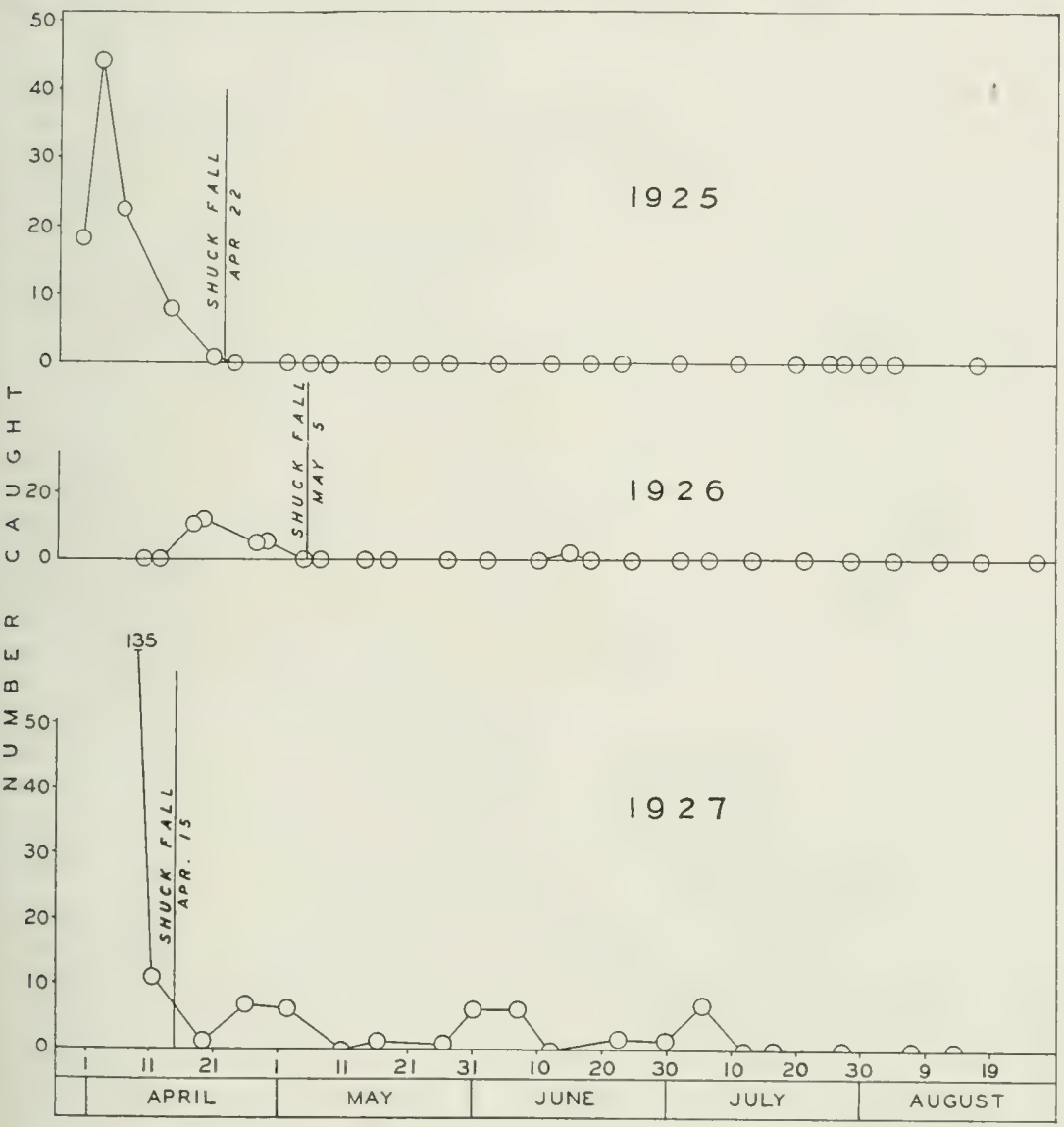

Fig. 20.- Records of tarnished plant bug occurrence. Ten unsprayed trees were jarred between 6 and 7 a.m. over a period of five months in each of the three years given, showing that few to none of the insects remain in the trees after shuck fall.

10 per cent of the Illinois peach crop. There are few, if any, years in which the insect does not cause blemishes on 2 per cent of all peaches grown in the state. Catfacing is the most common injury inflicted by the bug. This sometimes ap- 
pears as closed lesions varying from slight dimples to extensive puckered areas, fig. 19. No pubescence develops on the injured places. The damage is worked early in the development of the fruit and it may be localized on a given tree, some branches having no affected fruit although others may have a large part of their peaches disfigured.

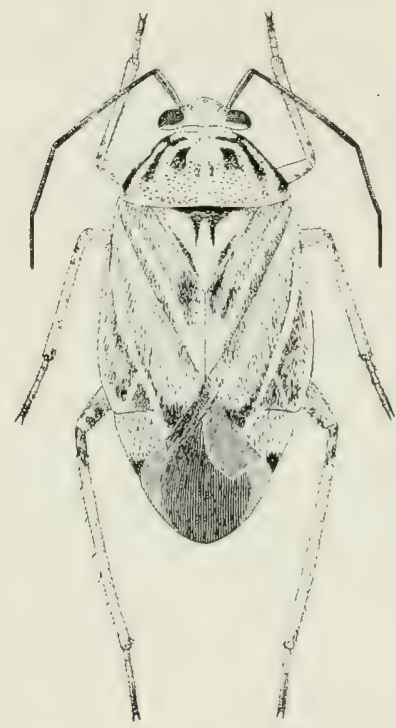

Fig. 21.- Adult tarnished plant bug, Lygus pratensis (L.). Twelve times life size.

Less important, except in seasons of very light set of fruit, is a second type of injury-death of the tiny fruit shortly after petal fall as a climax to injuries inflicted by the plant bug's feeding during the period of bloom.

Stopback or dieback is a third injury, chiefly important to nurserymen. The plant bug causes this wilting or dying back of new growth by sucking the sap from the tender terminals and evidently injecting there some toxic substance.

control.-Much time has been devoted to elimination of the tarnished plant bug in Illinois, Indiana and other states, without a satisfactory control measure having been developed. Being a sucking insect, the bug must be poisoned by contact poison. It is very active and hard to hit with any spray or dust. Any possible application of such treatment has to be made very early, immediately after petal fall, as nearly all the bugs have left the peaches by shuck fall, as is indicated in fig. 20.

Cultural control.-Elimination of weeds in and about the peach orchard may decrease infestation. Observations show a connection between legumes in and close to orchards and increase of catfacing.

Thiming.- While thinning cannot be classed as a control measure it is a means of reducing losses from catfacing. 

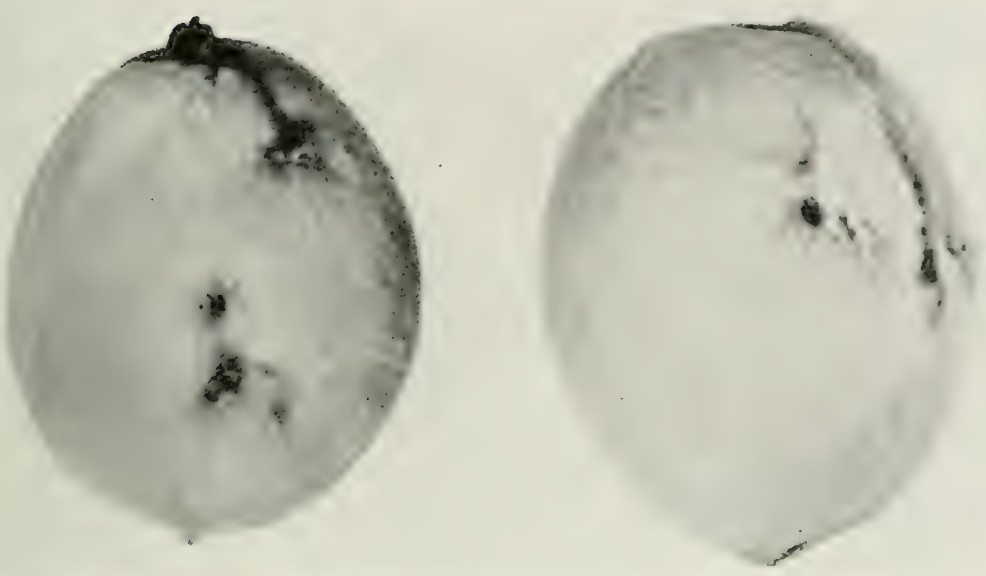

Fig. 22.- Injury to fruit by adult of the stink bug Euschistus tristigmus (Say).

The injured fruits may easily be detected as the peaches become larger. Experiments by Dorsey and McMunnt indicate that effective thinning may be done as late as four weeks before harvest. Many growers are now taking advantage of this discovery to eliminate defective fruit.

LIFE HISTORY.-The adult is a coppery brown insect flecked with darker brown and yellow, oval shaped and about a quarter-inch long, fig. 21. In this state it passes the winter hidden in many kinds of shelter, but it prefers wild parsnip, alfalfa, clover, and most of all, mullein. So greatly is the latter preferred that we have used the number of bugs

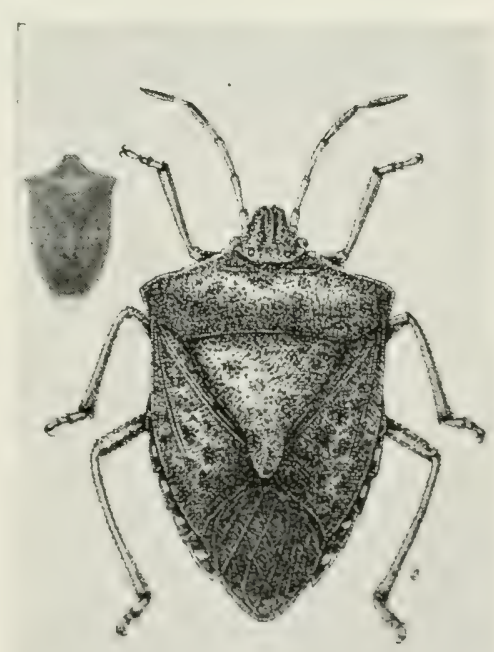

Fig. 23.-Adult of the stink bug Euschistus servus (Say). Inset shows approximate life size.

" "Development of Peach Seed in Relation to Thinning," by M. J. Dorsey and R. L. McMunn. American Society of Horticultural Science, 1920, p. 40 ?. 
found hibernating in it as an index to abundance of the insect.

In early spring the adult becomes active and flies to the trees. It leaves them rather early in the development of the fruit and then feeds on a variety of crops, seeming to prefer legumes and certain weeds.

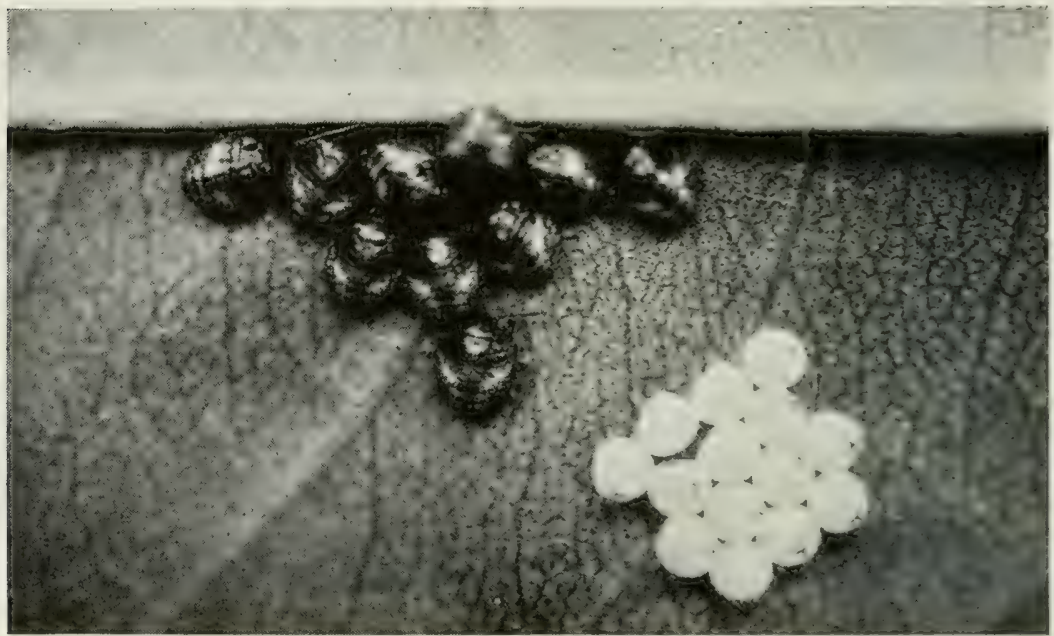

Fig. 24.-Colony of small stink bugs clustered on leaf near egge mass from which they hatched. About six times life size.

\section{STINK BUGS}

\section{Euschistus euschistoides (Voll.) Euschistus tristigmus (Say) Euschistus servus (Say) \\ Euschistus variolanus (Beauv.)}

APPEARANCE AND TYPE OF InJURy.-Two types of injury, catfacing and dimpling, are caused by the stink hug, fig. 22 . The green soldier bug, as one kind of stink bug is commonly called, specializes in dimpling the fruit, while at least four species and probably more are known to cause catfacing in Illinois and Indiana, continuing to produce the injury fire or six weeks after petal fall.

control.-No practical control measure for this insect exists.

LIFE mistory. - Stink bugs hate a modified triangular form about a half-inch long and a quarter-inch wide, fig. 23, and 
are usually brownish green. They hibernate as adults and first appear on the peach about petal fall. A few species lay small groups of eggs on the peach tree leaves, fig. 24 . After the young hatch they cluster about the egg mass for a few days until they undergo the first molt. Then they leave the peach trees and may be found in large numbers in fields of cowpeas and soybeans. They also feed extensively on weeds, particularly on one of the fleabanes, Erigeron canadensis, commonly called butterweed or horseweed.

\section{JAPANESE BEETLE}

Popillia japonica Newm.

APPEARANCE AND TYPE OF InJURy.--The Japanese beetle is a robust, bronze and green beetle about a quarter of an inch wide and one-third of an inch long, fig. 25. The wing covers are bronze with a triangular shieldlike area just behind the head. There are four white dots on the tip of the abdomen, which protrudes from under the wing covers. It has been found in most of the states to the east and is sure to reach Illinois within a few years, if it is not already here.

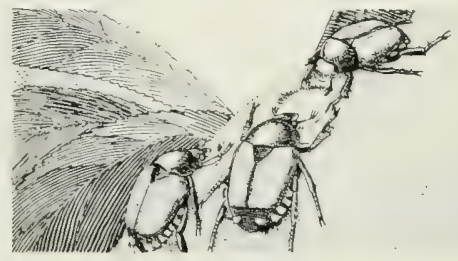

Fig. 25. - Adults of Japanese beetle, Popillia japonica Newm., attacking fruit. Slightly more than life size.

The injury to peach occurs entirely from the beetles feeding on the ripe or nearly ripe fruit. 'They do not feed on green fruit, but just as the peaches are beginning to ripen the beetles descend upon them, and in areas where the insect is abundant will eat almost all the fruit on the trees or will break the skin and gouge the fruit in such a way that it is rendered unmarketable. Clusters of the beetles will be found on the fruit, sometimes 50 or more on a single peach. controL.-Spraying with the materials ordinarily recommended for the control of curculio is of some value in repelling the beetles. Trapping and the use of repellent sprays 
or the other methods which have been found of value may be used. If the insect is found, special recommendations will be made for its control. Anyone seeing an insect of this sort feeding on the peach is urged to send it at once frot identification to the chief entomologist, State Niturat History Survey, Urbana, Illinois.

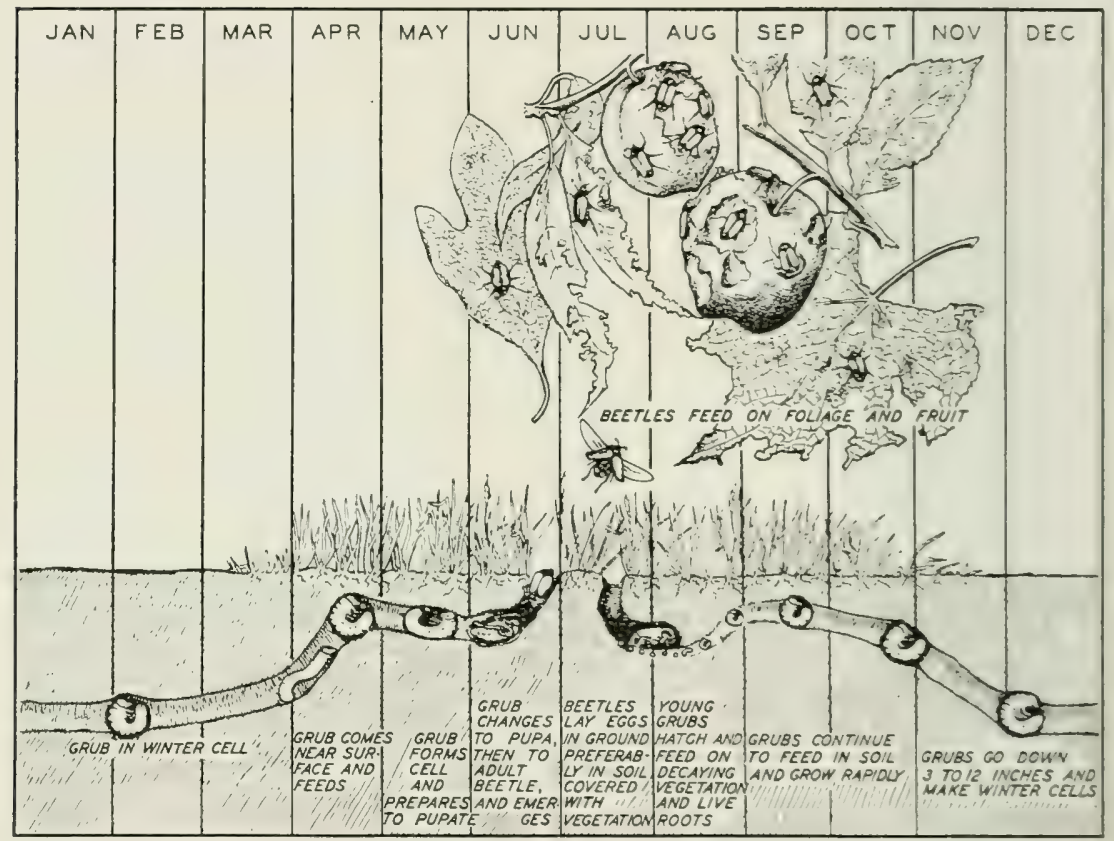

Fig. 26. - Life history of the Japanese beetle. [Adaptation, courtesy Pa. Dept. Plant Industry.]

uIFE History.-The Japanese beetle in most of its range has one complete brood each rear, fig. 26. In certain parts of eastern United States where the soil is wet and cold there may be only one brood in two years. The winter is passed only in the grub stage in a cell several inches deep in the soil. In the spring the grubs go into the pupal or changing stage, in which they remain for several weeks. They start emerging as beetles in June and continue to emerge during August and in small numbers in September.

The eggs are ladid singly in the soil and hatch in alout 
two weeks into small grubs. 'These feed at first on decaying vegetable matter and to a very slight extent on living plant roots. Most of them become full grown by the approach of cold weather, and all form the protective cells in the soil in which they winter.

\section{GREEN JUNE BEETLE}

Cotinis nitida (L.)

APPEARANCE AND TYPE OF INJURY.-The green June beetle found in southern Illinois feeds on a wide variety of plants and occasionally attacks peaches just before ripening.

conTROL.-As no arsenic spray can be used at the time, no control other than jarring or hand picking avails. Manure piles in the vicinity of orchards may act as breeding places for the insect and should be removed.

LIFE HISTORY.-The beetle is a conspicuous green, about three-quarters of an inch long and somewhat flattened, fig. 27. The larva is a dirty white grub which feeds on decaying vegetation and is recognized by the habit of crawling on its back, fig. 28 .

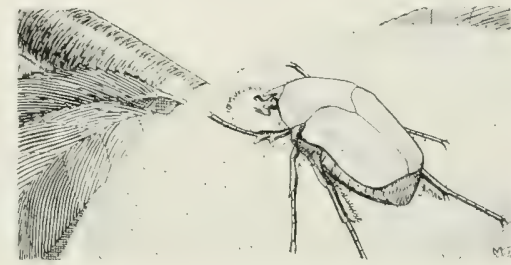

Fig. 27.-Adult of green June beetle, Cotinus nitida (L.), attacking fruit. Life size.

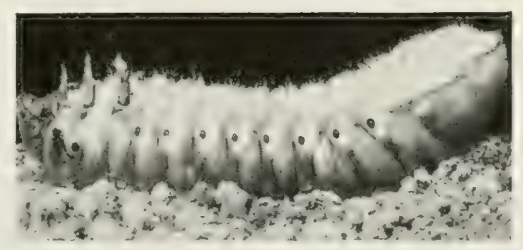

Fig. 28.- - Larva of the green June beetle in characteristic position, crawling on its back. One and one-half times life size. [Courtesy U. S. Bur. Ent.]

\section{COTTON LEAF WORM MOTH}

Alabama argillacea $\mathrm{Hbn}$.

APPEARANCE AND TYPE of InJury.--This is the only moth found in Illinois which in the adult stage is capable of puncturing the skin of such fruits as peach, grape and apple. The moth chiefly attacks the ripe peaches of late varieties, such as 
Krummel's October and Heath cling, on which it may be seen in very large numbers. Though the moths may puncture the skin, they feed extensively through cracks in it, fig. 29. Brown rot usually results from this feeding.

control--Application of sulfur helps to control the brown rot which follows the moth injury, and may have some repelling effect on the moths.

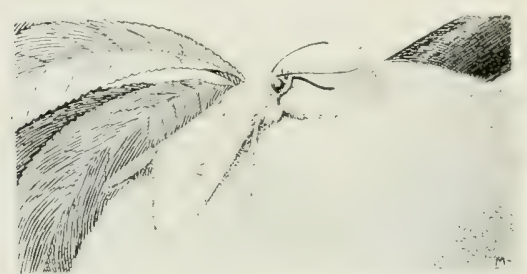

Fig. 29. - The cotton leaf worm moth, Alabama argillacea Hbn., feeding on fruit. Life size.
LIFE HISTORY.-The moth is about $1 \frac{1}{4}$ inches from tip to tip of wing, and is olive tan with three wavy transverse bars on each front wing. It is a tropical insect and does not winter in the United States. A strong flier, it travels as far north as Canada.

\section{APHIDS}

Aphis persicae-niger Smith

Myzus persicae (Sulz)

aPPEARANCE ANd TyPE OF InJuRy.-Greenish aphids or plant lice occasionally are found sucking the sap from twigs of new fruit. Two of the more important in Illinois are the black peach aphid and the green peach aphid.

control.-Aphids rarely become of sufficient importance in Illinois peach orchards to justify control measures. A 40 per cent nicotine sulfate solution, 1 pint to 100 gallons, with 2 pounds of potash fish oil, will kill the aphids when the spray is applied thoroughly enough to strike their bodies.

\section{GRASSHOPPERS}

\section{Melanoplus spp.}

APPEARANCE AND TYPE OF INJURY.-(Ocatsionally grasshoppers become sufficiently numerous in a peach orchard to cause serious damage to foliage and bark of twigs.

control.- [se of poison bran mash is an excellent control measure. Arsenic sprays used for plum curculio are partially 
effective. Illinois Natural. History Survey Circular 5, "Methods of Destroying Grasshoppers," ${ }^{5}$ gives the following information:

One of the most effective ways of destroying grasshoppers is by the use of a poisoned bait attractive to them. The medium most generally and successfully used for this purpose is a bran mash. This is prepared by mixing together the following:

25 lbs. dry bran

$1 \mathrm{lb}$. white arsenic or $1 \mathrm{lb}$. Paris green.

Mix into a stiff mash by adding about 3 gallons of water into which has been stirred 2 quarts of cheap molasses, black strap preferred.

\section{TREE CRICKETS}

Oecanthus nigricornis Walker

APPEARANCE AND TYPE OF INJURY.-Tree crickets occasionally cause slight injury to peach by laying rows of eggs in the twigs, 50-75 eggs in a row and about 25 to the inch. The twig may die above the series of punctures. Eggs are pale yellow and about oneeighth inch long.

CONTROL.-Control of tree crickets has never been necessary on peach in Illinois. It is probable that ordinary spraying and dusting holds down infestation.

LIFE HISTORY.-Adult tree crickets are very slender green insects with antennae or feelers longer than the body, fig. 30. One generation occurs each year. Eggs are deposited in the fall; in this stage the insect winters and hatches in spring. The

${ }^{5}$ By W. P. Flint. 1919. (Out of print.)

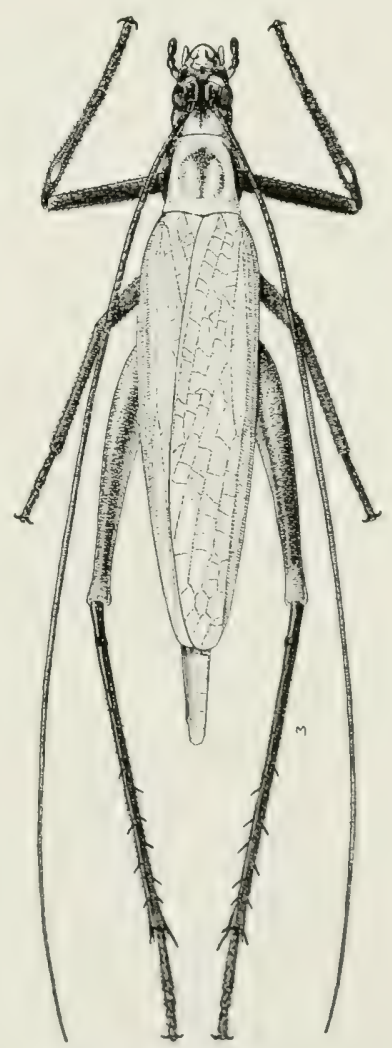

Fig. 30.-Adult female of a tree cricket, Oecanthus nigricornis Walker. Four times life size. 
adult male produces chirping notes by rubbing together specially modified parts of the forewings.

\section{THRIPS}

\section{Frankliniella spp.}

Tiny yellow insects called thrips have been quite generally accused of causing catfacing. Experimental work, field examinations and observations both in this state and in Indiana have proved definitely that such is not the case.' These insects are often found in very large numbers in the peach blossoms but there is very little evidence of accompanying injury.

"6ome Causes of Catfacing in Peaches," by B. A. Porter, S. C. Chandler and R. F. Sazama. Ileinors Natural Histori Survel Bulletix 17(6): 261-75. March 1928. Publication 196. 





\title{
CURRENT PUBLICATIONS
}

\author{
of the Illinois State Natural History Survey
}

A.-ILLINOIS NATURAL, HISTORY SURVEY BLLLETIX. Volume XX.

Article I. - Initial Studies of American Elm Diseases in Illinois. By Hubert A. Ilarris. October 1932. 70 pp., 35 figs. Partial eontents: Character of the present elm malady, Laboratory methods, General results of eultural tests, Specific discases, Other infections, Inoculation trials. Preliminary control experiments. Fifty cents.

Article II.-A Survey of the Fishery of the Kaskaskia River. By Wilhur I. Luce. August 1933. 52 pp., 12 figs. Partial contents: Iydrography. Methods and equipment, Value of the fishery, Kinds and numbers of mussels, Kinds of fishes caught with various tackle. Factors affecting abundance, Rate of growth, Large fishes, Small fishes. Fifty cents.

Arlicle III.- The Dermaptera and Orthoptera of Illinois. By Morgan Hebard. November 1931. 155 pp., front. + 167 figs. Partial contents: Biology and habits of the orders, Eeological factors affecting Orthoptera. Key to the orders, Description of species, Control measures. $\$ 1$.

Article IV.-The Stonefles, or Plecoptera, of Illinois. By Theodore II. Frison. January 1935. 191 pp., front. + 311 figs. Contents: Status of the group; Stonefly structure; Biology of the order; Collecting. rearing and preserving stoneflies; Catalog of species, including classification. description, habits and reerds of Illinois stoneflies, and new elassification of North American forms. \$1.25.

\section{3. -IILINOIS NATURAL IISTORY SURVEY CIRCELIR.}

24. Care of Trees. By L. E. Sawyer. February 1932. 7 pp., 5 figs. Contents: Watering. Fertilization, Trimming. Surgery. Publieation 223.

25. How to Collect and Preserve Insects. By II. H. Ross. February 1934. 27 pp., 11 figs. Partial contents: Where to collect. What to use, How to handle unmounted specimens, How to mount and preserve the colleetion. How to babe! the specimens. Housing the collection permanently. Publication 212.

\section{C.-IILINOIS NITURII, HISTORI GLRVE BOOKIIST.}

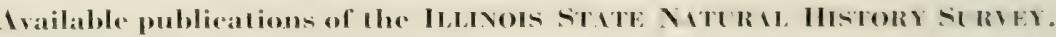
Mareh 1935. 13 pp., 257 tilles.

Address orders and correspondence to the Chicf.

\section{IILINOIS STATE NATURAL, HISTORY SURVEY}

Natural History Bldg., Urbana, III. 





\section{UNIVERSITY OF ILLINOIS-URBANA}

570IL6C

CIRCULAR

25-36 1934-47

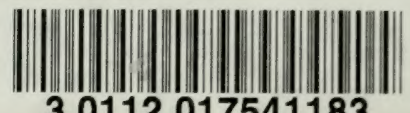

30112017541183 